\title{
Diminutive formation in Hungarian
}

\author{
PÉTER REBRUS $^{1}$ (1) and PÉTER SZIGETVÁRI ${ }^{2^{*}}$ (1)
}

\author{
${ }^{1}$ Hungarian Research Centre for Linguistics, Budapest, Hungary \\ ${ }^{2}$ Eötvös Loránd University, Budapest, Hungary
}

Received: March 16, 2021 • Accepted: May 17, 2021

Published online: June 25, 2021

(C) 2021 The Author(s)

\section{ABSTRACT}

We survey templatic diminutive formation in Hungarian. We conclude that there is an intricate system of endings that are added to bases which are truncated if they contain more than one vowel. Bases are also subject to vowel length changes in both directions, as well as the palatalization of the last consonant. The templatic diminutive forms are not subject to vowel harmony occurring in suffixes which prevails in the regular additive morphology of the language. Nevertheless, these forms conform to the vowel patterns found in disyllabic monomorphemic or disyllabic suffixed word forms.

\section{KEYWORDS}

Hungarian, diminutives, templatic morphology, truncation, vowel harmony

In this paper we examine various types of diminutive formation in Hungarian and show that truncative diminutives exhibit unique behaviour in several respects as compared to all other types of morphological processes. These forms are templatic, conforming to an intricate system of templates containing a fixed final vowel (in some cases the last two vowels are invariant), and potentially a consonant either after or before this vowel.

We are unaware of such a catalogue of templatic diminutive forms in Hungarian. Vago (1980), van de Weijer (1989), or Kiefer \& Ladányi (2000b, 170ff) discuss the type of diminutive formation we describe in this paper, but touch upon a single template, albeit the most common one, -i. Other accounts (Bárczi 1931-1932; Tompa 1964; T. Somogyi 2017) offer many data, but are more or less unsystematic. Also many words listed especially by Bárczi became obsolete in the past decades. There is more extensive literature about similar forms in other

\footnotetext{
${ }^{*}$ Corressponding author. E-mail: szigetvari@elte.hu
} 
languages (Prieto 1992; Thornton 1996; Itô \& Mester 1997; Schneider 2003; Alber \& ArndtLappe 2012; Kenstowicz 2019).

The paper begins with a brief introduction to the phoneme inventory of Hungarian $(\$ 1)$. We then define what we mean by a "diminutive" form: we use this as a cover term for a wider semantic/pragmatic field, including hypocoristics, humorous, slangy, informal words, whose phonological shapes are similar $(\$ 2)$. We then introduce what we call additive (or concatenative or agglutinative) morphology, which constitutes the bulk of morphology in Hungarian (\$3). In a rather limited se of cases we find vowel-zero alternation in additive morphology, (\$4). This process is distinct from truncation $(\$ 5)$, a characteristic only of the formation of templatic diminutives. The catalogue of diminutive templates follows in the next section (\$6), with a subsection for each template vowel. We briefly discuss the role of reduplication (\$7), and the curious absence of vowel harmony in diminutive forms (\$8). Conclusions discussing the differences between additive and truncative morphological processes end the paper $(\$ 9)$.

\section{VOWELS AND CONSONANTS IN HUNGARIAN}

The reference accent of Hungarian distinguishes between seven short vowels. It contains the canonical five-vowel inventory complemented by two front rounded vowels. The textbook tradition holds that each of the seven vowels has a long counterpart. A number of morphophonological alternations support this analysis and the standard spelling also reflects it. We list these vowels in (1).

The vowel system of Hungarian

\begin{tabular}{lccc}
\hline & front unrounded & front rounded & back \\
\hline high & i i: & y y: & u u: \\
mid & - e: & $\emptyset ~ ø: ~$ & o o: \\
low & $\varepsilon_{-}$ & & a a: \\
\hline
\end{tabular}

The transcription symbols we use in this paper suggest that there is also a quality difference between the low $([\mathrm{a}]-[\mathrm{a}]])$ and the front unrounded nonhigh short-long pairs $([\varepsilon]-[\mathrm{e}:]) .{ }^{1}$ In the reference accent $[\varepsilon]$ alternates both with mid the vowels $[\varnothing]$ and $[o]$ and with the low $[a]$ due to backness and/or roundness harmony, cf. \$3. Furthermore, its long counterpart [e:] alternates only with the low [a:], not with mid [ø:] and [o:]. We categorize $[\varepsilon]$ as a low vowel because of its behaviour with respect to vowel harmony, specifically the Height Effect (Hayes et al. 2010): $[\varepsilon]$ exhibits less characteristics of neutrality than [e:], which in turn exhibits less characteristics of neutrality than $[\mathrm{i}]$ or $[\mathrm{i}$ ] . Another reason for assigning $[\varepsilon]$ and $[\mathrm{a}]$ to a natural class is that they both lengthen before suffixes, cf. (4f).

In (2) we tabulate the consonant phonemes of Hungarian. We take [j], [v], and [h] to be approximants, not fricatives (the latter two contra Siptár \& Törkenczy 2000, 76ff), although all three consonants have fricative allophones. The status of [k] is debatable: most of its

\footnotetext{
${ }^{1}$ A lesser quality difference also exists between the other mid vowel pairs, [ø]-[ø:] and [o]-[o:], but this is often ignored in transcriptions. Lass (1984) transcribes these vowels as [œ], [ø:], [ग], [o:], respectively. In this paper the choice between the two analyses is irrelevant, so we apply the simpler set of symbols.
} 
occurrences are geminates suggesting that it is a $[\mathrm{d}]+[\mathrm{z}]$ cluster. In our transcriptions we will include $[\mathrm{y}]$, the nasal occurring before velar plosives.

The consonant system of Hungarian

\begin{tabular}{|c|c|c|c|c|c|c|}
\hline & labial & dental & postalveolar & palatal & velar & glottal \\
\hline plosives & $\mathrm{pb}$ & $\mathrm{td}$ & & $c f$ & $\mathrm{~kg}$ & \\
\hline affricates & & ts (d) & $t$ & & & \\
\hline fricatives & $\mathrm{f}$ & s Z & $\int 3$ & & & \\
\hline nasals & $\mathrm{m}$ & $\mathrm{n}$ & & $\mathrm{n}$ & & \\
\hline approximants & $v$ & r l & & $\mathrm{j}$ & & $\mathrm{h}$ \\
\hline
\end{tabular}

Hungarian has voicing assimilation of obstruents: adjacent obstruents agree in voicing. The voicing of an obstruent cluster is determined by its last member. This is also true of clusters separated by a word boundary. So [ty:z] 'fire'+[kø:] 'stone' is [ty:skø:] 'flint', while [ørøk]+ [zøld] is [ørøgzøld] 'evergreen'.

The dental nasal assumes the place of articulation of a following occlusive and loses its occlusion before a following nonocclusive. So [ke:n]+[por] is [ke:mpor] 'sulphur powder',

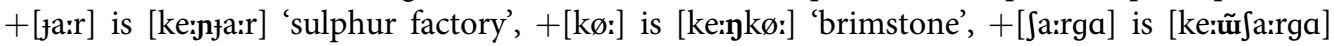
'sulphur yellow'.

Hungarian has two palatal plosives, $[\mathrm{c}]$ and $[\mathrm{f}]$, the nasal $[\mathrm{n}]$, as well, as the approximant [j]. At a stem+suffix boundary the dentals [t], [d], and [n] merge with a following [j] into [cc], [ $\mathrm{f}]$, and $[\mathrm{n}]{ }^{2},{ }^{2}$ respectively, or into their short variant if the dental occurs in a cluster $([\mathrm{bot}]+[\mathbf{j a}] \rightarrow$ [bocca] 'stick-3SG.POSs', [pont] $+[\mathbf{j a}] \rightarrow$ [ponca] 'point +3 SG.POSs'). In the same environment $[1]+$ [j] surface as [jj] ([tol] $+[\mathbf{j a}] \rightarrow$ [tojja] 'push-3SG.DEF_oBj').

\section{DIMINUTIVES}

We are going to compare diminutive forms to their nondiminutive counterparts, which we call their base. This is important, because there are some regularities that can only be formulated by reference to the base. A base can often be associated with several diminutive forms ([mari], [ma:ri], [marif], [martfi], [mara], [martfa], [mani], [mantsi], [mares] are all diminutives for the name [ma:rija], ${ }^{3}$ and [oksi], [oksi], [okfa], [okJ], [okes], [okker] are all diminutives for [oke:] 'okay').

We use the term diminutive (DIM) for several different semantic categories, which do not seem to be distinguished morphophonologically in Hungarian. Some of these forms are hypocoristics, terms of endearment or belittling, others are simply informal, slangy, or humorous versions of their base. Kiefer \& Ladányi claim that diminutive forms have no semantic correlates, their use is governed by pragmatic factors $(2000 \mathrm{~b}, 171)$. In Hungarian none of these forms can be used exclusively as vocatives, unlike in Italian (Alber 2010). Since a semantic/pragmatic

\footnotetext{
${ }^{2}$ In transcriptions we represent long vowels using the IPA length mark, but geminate consonants by doubling the relevant symbol.
}

${ }^{3}$ Words without a gloss are names, typically given names, in some cases family, animal, or geographical names. 
delineation of diminutive forms is rather uncertain, we are going to compare the phonological shape of potential diminutive forms to their bases when there appears to be a firm semantic connection between the two.

The base of most diminutive forms is a noun, typically a given name, but it may also be a common noun, as well as a family or a geographical name. In addition, we also find adjectives ([unalma $]>^{4}$ [untfi] 'boring', [puha] > [puhi] 'soft'), adverbs ([komoj(an)] > [komtfi] 'serious(ly), [tfuda] > [tfudi] 'awfully'). Verbs in present-day Hungarian are coined by suffixing [z] or [1] to their stem. ${ }^{5}$ No diminutive template ends in either of these consonants, accordingly verbal diminutives must contain

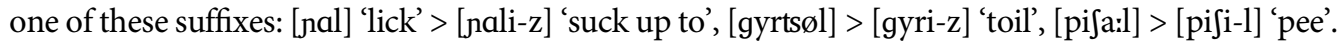
However, suffixless diminutive verbs occur as second person imperatives: e.g., [mutat] 'show' > [muti] 'show-2SG.IMP', [fijcl] 'listen' > [fiji]/[fiju] 'listen-2SG.IMP'. 6

Some words whose phonological form satisfies the formal criteria of diminutives (and are in most cases etymologically diminutive forms) have lexicalized nondiminutive meanings ([sa:l] 'thread', [sa:lka] 'splinter'; [na:l] 'saliva', [na:lka] 'slime'; [pata] 'hoof, [patko:] 'horseshoe'; [tfal] 'cheat', [tfali] 'bait', in the last case the word category is not preserved: [tfal] is a verb, [tfali] is a noun).

There are also cases where both the meaning and the phonological form of a word form is diminutive-like, but there is no other word in the current language which it could be synchronically related to, which could be identified as its base ([bifo:] 'thingy', [bili] 'potty', [buno:] 'punch-up', [tsumi] 'pacifier', [tsumo:] 'stuff, [duci] 'prison', [melo:] 'work', [muci] 'illegal business', [tuti] 'certain'). ${ }^{7}$

In yet other cases there is a semantically identifiable base, but the phonological connection is unprecedented. This occurs either because the base became obsolete ([lasti] 'ball.DIM', from an earlier [Elastik], a brand name (Bárczy 1931-1932), cf. [labda] 'ball'; [fitsko:] 'guy', from an earlier

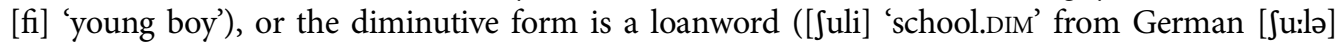
'school', cf. Hu [ifkola] 'school'; [no:zi] 'nose.DIM' from Yiddish [noz] 'nose', cf. Hu [or:] 'nose'; [braco:] 'older brother.DIM' from Slovak [brat] 'brother', cf. Hu [ba:c(c)] 'older brother', etc.).

Language historians identify a number of further words as diminutives, like [petc], [petø:]

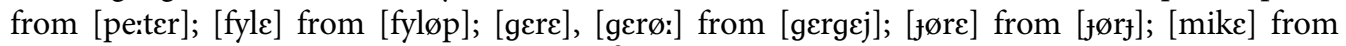

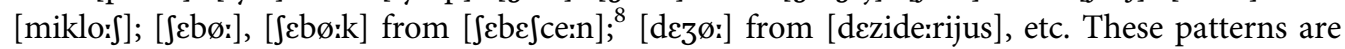
not productive and most speakers do not identify these forms as diminutives. We will ignore such pairs in this paper, that is, we do not posit diminutive templates that they fit in. Let us note here, that these diminutive endings harmonize, unlike any of the truncative diminutives endings we have identified.

\footnotetext{
${ }^{4} \mathrm{We}$ use the greater-than sign not to mean 'turns into', but to symbolize that the base form is semantically 'greater than' the diminutive to its right.

${ }^{5}$ Adjectives are optionally also subject to being suffixed by [J], as in the diminutives [rafina:lt] > [rafko:- $\left.\int\right]$ 'cunning', [bubore:kof] 'bubbly' > [bubi-f], [topronłof] 'dilapidated' > [topi-f].

${ }^{6}$ Although imperative and subjunctive forms are syncretic in Hungarian, suffixless diminutive verbs cannot be used as subjunctives. The subjunctive must contain a stem with a verbalizer suffix ([z]) and the 2SG.SBJV.DEF and 2SG.SBJV.NDF suffixes ([d] and [z], respectively): *[ke:rlek muti/fifu], [ke:rlek muti-z-d/fiju-z-z] 'I ask you to show it/listen'.

${ }^{7}$ Again some of these are loans that happen to have diminutive-like phonological shapes: [melo:] is from Yiddish [meloxo] 'work', [muci] from French [mwatje] 'half, [tuti] from Viennese slang [tutti] 'perfect' (in turn from Italian [tutti] 'all').

${ }^{8}$ These former diminutive forms survive only as nondiminutive family names in present-day Hungarian.
} 
We must admit that some of the examples in this paper are debatable. Although we have consulted TESz (an etymological dictionary of Hungarian, Benkő et al. 1967) for etymologies, the authors of this dictionary are also often uncertain. The data were gathered from a web corpus (Szószablya, Halácsy et al. 2004), Ladó \& Bíró (2005), Janurik (2009), T. Somogyi (2017), web forums and blogs (like Papp 2018), as well as our native speaker competence. In some cases we have based our decisions on our own intuitions.

Diminutives can be formed by additive and also by truncative morphology. Additive diminutives follow the regularities shown by most other additive morphological processes of the language, briefly described in $\$ 3$ (the stem is not truncated, the suffix either harmonizes with the stem vowel(s) or contains a netural vowel, etc.), therefore they are irrelevant for the purposes of this paper. Truncative diminutives, on the other hand, are radically different. For the sake of the comparison, we first introduce some features of additive morphology in Hungarian.

\section{ADDITIVE MORPHOLOGY}

The bulk of Hungarian morphology is additive, involving mostly suffixation. This means that phonological material is added to the end of the stem, which itself appears in its entirety (Kiefer \& Ladányi 2000a, 140). Put alternatively, words typically have free stems. Some examples are provided in (3).
Additive morphology
a. [kapu] 'gate', [kapu-t] 'gate-ACC', [kapu-nak] 'gate-DAT'
b. [lø:] 'shoot', [lø:-s] 'shoot-2SG.PREs', [lø:-nck] 'shoot-3PL.PREs'

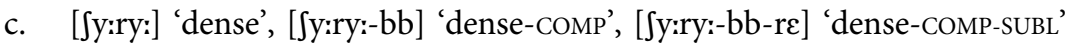
d. [mano:] 'goblin', [mano:-ka] [mano:-tfka] 'goblin-DIM'

The stem may undergo relatively minor changes, thereby becoming a bound stem. These changes include the loss of the independent place or voice specification of the stem final consonant, as in (4a) and (4b), or its palatalization caused by a suffix-initial [j], as in (4c). A consonant, (4d), or a vowel, (4e), may also occur between the stem and the suffix. This "augment" is only marked in this display, later on we will mark it as belonging to the suffix. A stem-final low vowel lengthens before most suffixes, (4f). The last vowel of the stem may shorten in suffixation. This shortening may occur to low vowels, (4g), high vowels, (4h), and mid vowels too, (4i). (Mid [e:] shortens to low [ $\varepsilon$ ], so examples for this pair are listed for both categories.) We also find vowel-zero alternation in stems. It is most commonly $[\varepsilon]$, [o], and $[\varnothing]$ that alternate with zero, (4j). Long vowels do not alternate in this context.

(4) Stem changes in additive morphology
a. [se:n] 'coal', [se:m-ben] 'coal-INE'; [iftua:n], [iftua:n-ka] 'I-DIM'

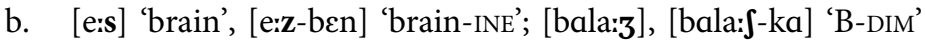
c. [pad] 'bench', [pa-fa] 'bench-3SG.POss'; [sa:n] 'pity', [sa:n-ja] 'pity-3SG.DEF'
d. [bø:] 'opulent', [bø:-v-yl] 'opulent-vRBz'; [falu] 'village', [falu- $\left.\int-\mathrm{i}\right]$ 'village-ADJz'
e. [tøk] 'pumpkin', [tøk-ø-k] 'pumpkin-PL'; [rum] 'rum', [rum-o-t] 'rum-ACC'
f. [fa] 'tree', [fa:-k] 'tree-PL'; [kefe] 'brush', [kefe:-t] 'brush-ACC'
g. [na:r] 'summer', [nar-at] 'summer-ACC'; [te:l] 'winter', [tel-et] 'winter-ACC' 
h. [vi:z] 'water', [viz-et] 'water-ACC'; [ty:z] 'fire', [tyz-et] 'fire-ACC', [u:t] 'road', [ut-at] 'road-ACC'

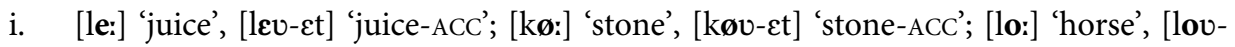
at] 'horse-ACC'

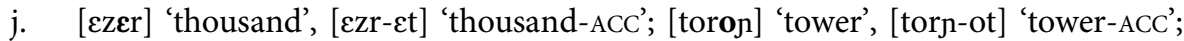
[økøl] 'fist', [økl-øt] 'fist-ACC'

Many suffixes in additive morphology exhibit vowel alternations that are governed by front/back or both front/back and rounding harmony. There are also suffixes, overwhelmingly containing a front unrounded vowel, that do not harmonize, (5h). Vowel harmony can be detected in many of the examples above, we here give a brief summary. For more complete descriptions, see Törkenczy (2011; 2016), Rebrus \& Törkenczy (2019).

Harmony in suffixes

a. [nu:l-nak] 'rabbit-DAT'; [fyl-nek] 'ear-DAT'; [sil-nek] 'elm-DAT'

b. [nu:l-hoz] 'rabbit-ALL'; [fyl-høz] 'ear-ALL'; [sil-hez] 'elm-ALL'

c. [ni:l-nak] 'arrow-DAT'; [tse:l-nak] 'goal-DAT'

d. [profil-nak] 'profile-DAT'; [kafte:j-nak] 'castle-DAT'

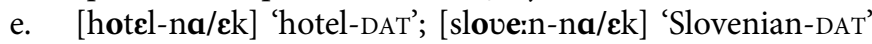

f. [tsivil-nek] 'civil-DAT'; [vide:k-nek] 'land-DAT', [fe:tif-nek] 'fetish-DAT'

g. [hi:g] 'diluted', [hi:g-abb] 'diluted-COMP', [hig-i:t-ok] 'diluted-VRBZ-1.SG_INDEF.OBj'

h. [na:r-i] 'summer-ADJZ'; [ø:s-i] 'autumn-ADJZ'; [te:l-i] 'spring-ADJZ'

(5a) shows the most robust pattern, front/back harmony: the suffix occurs in its front- or back-vowelled allomorph depending on the front or back quality of the stem vowel. Rounding harmony is parasitic on front/back harmony: it is only a harmonizing short front vowel that may agree with the rounding of the stem vowel and only when it also harmonizes in frontness, (5b). It is a lexical property of suffixes if they have one (front unrounded), two (front and back), or three (front rounded, front unrounded, and back) allomorphs. The choice is also dependent the height of the vowel, the three-way alternation is only available with short mid $[\varnothing]-[\varepsilon]-[o]$.

Front unrounded vowels are called neutral vowels. They often exhibit disharmonic behaviour. This is manifested in antiharmony, (5c), or in transparency, (5d), as well as the fact that almost all suffixes that do no alternate harmonically contain a neutral vowel. ${ }^{9}$ The high [i] is almost always transparent, [e:] may be transparent, (5d). In many words containing [e:] and $[\varepsilon]$, we find vacillation, (5e). Antiharmonic roots ${ }^{10}$ are almost exclusively monosyllabic: in them a neutral (i.e., front) vowel, most often [i(:)], sometimes [e:], governs back harmony, (5c). A monomorphemic, disyllabic stem is almost never antiharmonic, (5f). ${ }^{11}$ A polymorphemic stem, however, may be antiharmonic. In (5g) the stem contains two neutral vowels, just like [tsivil] in (5f).

\footnotetext{
${ }^{9}$ In unsuffixed words containing both front and back vowels, the front ones are typically unrounded, i.e., neutral.

${ }^{10} \mathrm{By}$ root we mean the first morph in the word. The stem of a word is what remains when the last suffix is removed. That is, a root is a monomorphemic stem.

${ }^{11}$ The rare exceptions are [dere:k] 'waist', [fe:rfi] 'man', and potentially [ize:] 'thingy'.
} 
But the root [hi:g] is antiharmonic (as the comparative form shows). The suffix immediately following the root also contains a nonharmonizing neutral vowel, thus [hig-itt] is a disyllabic stem containing two neutral vowels. Crucially, this stem is polymorphemic and it preserves the harmonic properties (back harmony) of its root, [hi:g]: [hig-i:t] governs back harmony, because its root, [hi:g], governs back harmony. We will refer to this property of harmony as Harmonic Uniformity (Rebrus \& Szigetvári 2016). We return to Harmonic Uniformity in $\$ 8$.

\section{THE LOSS OF A WORD-FINAL VOWEL}

In some cases a root may lose its ending even in what we categorize as additive morphology. This occurs only before a small set of derivational suffixes. It involves the loss of a single rootfinal vowel, short, as in (6a), or long, as in (6b). (All the suffixed forms include a verbalizer, we spare their gloss.)

(6) The loss of a word-final vowel
a. [ferde] 'skew', [ferd-yl]; [kuca] 'dog', [kuc-ul]; [be:ke] 'peace', [be:k-i:t]; [fekete] 'black', [feket-i:t]
b. [fako:] 'pale', [fak-ul]; [apro:] 'tiny', [apr-i:t]; [Javanu:] 'sour', [Javan-odik];

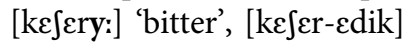

The loss of this vowel is linked to the verbalizing suffixes in (6), it is not merely a phonological motive (hiatus avoidance) that lies behind it. We do not find this loss before the homonymous essive-modal suffix ([me:rtse] 'gauge', [me:rtse:-yl]; [kuca] 'dog', [kuca:-ul]). This operation is different from the truncation observed in diminutive forms to be discussed in $\$ 5$ on at least two counts: (i) in only affects a single root-final vowel, (ii) in does not limit the size of the resulting word form.

\section{TRUNCATIVE MORPHOLOGY}

What we call morphological truncation only occurs in diminutive forms. As we have seen, truncation is different from the loss of a word-final vowel, (6), because it is not limited to a single vowel, but may affect longer strings, including consonants and multiple vowels. Truncation applies in diminutive forms because they must satisfy a template that contains a given number of syllables (= vowels). Templatic diminutive forms are one, two, or three syllables long, the two-syllable template accounting for the vast majority of examples. Since the point of truncation is to reduce the number of syllables in the stem to one, it will inevitably target at least one vowel: truncating only consonants does not influence the syllable count.

Vowel loss vs. truncation

a. [tørte:nclem] 'history', [tørte:nelm-i] 'history-ADJZ'; [somoru:] 'sad', [somor-i:t] 'sadVRBZ'

b. [tørte:nelem] 'history' > [tør|i] 'history.DIM'; [somoru:] 'sad', [som|i] 'sad.DIM'

c. [tista] 'clean', [tist-ul] 'clean-VRbz'; [be:na] 'lame', [be:n-i:t] 'lame-VRbz'

d. [tsitsa] 'cat', [tsits $\mid$ uf] 'cat.DIM'; [e:va] > [e:v $\mid \mathrm{i}]$ 
While in (7a) only a vowel is deleted from the stem before the adjectivizer and the verbalizer suffix. In (7b) a much longer string is lost from the stem before the diminutive ending. The reason why stems are so radically truncated in diminutive forms is that these forms must fit a disyllabic template. We split stems and diminutive endings by a vertical bar in (7) and below. We will encounter diminutive forms where the position of this vertical bar is indeterminate. In this case we omit it.

As shown in $(7 c-d)$, the output of vowel loss and truncation may coincide: truncation, $(7 d)$, may trim no more than a word-final vowel to create the base of a diminutive form, just like vowe loss occurring before certain verbalizers, (7c).

There are several diminutive templates. In addition to disyllabic diminutives, we also find a small number of trisyllabic and monosyllabic diminutive forms, although the analysis of the latter group is debatable. In template formulae we represent the truncated base by a dash: “-”. Thus we say that [tøri] satisfies the diminutive template - i. In the following we discuss the kinds of relationships there exist between nondiminutive bases, their truncated versions, and diminutive templates.

\section{DIMINUTIVE TEMPLATES}

The ending of all disyllabic diminutive templates is fixed. This ending contains minimally a vowel. In some endings this vowel is preceded or followed by a consonant too. The consonants preceding the template vowel come from a small set including [k] and voiceless sibilants, [s], [J], $[\mathrm{ts}$, and [t] (as well as the voiced [3] and [z], but only before [i] in two thinly populated templates). After the template vowel we may find [s] or an often optional [S]. Other consonants $([\mathrm{k}]$ and $[\mathrm{r}]$ ) only occur after one template vowel, $[\varepsilon]$. In fact, $[\varepsilon]$ is obligatorily followed by a consonant. There are no templates with a fixed templatic consonant on both sides. ${ }^{12} \mathrm{We}$ are going to catalogue the endings by their vowel.

Since the size of diminutive templates is fixed and most templates contain a vowel, the base of diminutive forms has to be truncated if longer than one syllable (in the case of disyllabic templates) or two (in the case of trisyllabic ones). Typically the end of the base is truncated, but it is sometimes the beginning (see Tompa 1964 for some examples). Initial truncation is more common with bases beginning with a vowel ([alfre:d] $>$ [fre:d|i], [alcksandra] $>$ [sand $\mid \mathrm{i}]$, [eleono:ra] $>$ [no:r $\mid \mathrm{i}]$ ), but is not restricted to them ([bernadett] $>$ [dett $\mid \mathrm{i}]$, [tsetsilija] $>$ [tsil $\mid \mathrm{i}]$ ). The truncated base is typically a contiguous substring of the original, although we find vowel length alternations, as we will show below. There are sporadic unexpected vowel quality alternations too ([tama: $\left.\int\right]>[$ tom $\mid \mathrm{i}]$, here the diminutive form does not show the historical $[\mathrm{o}]>$ [a] vowel shift, or $\left[f_{ø} \mathrm{r}_{\mathrm{f}}\right]>[$ [ $\left.u \mathrm{ur} \mid \mathrm{i}]\right)$. Furthermore, when a consonant cluster is trimmed at the end of a truncated base, it is not always the last consonant that is lost ([dolgozat] $>[$ dog $\mid \mathrm{a}]$ 'test', $[$ pifta] $>[$ pic $\mid$ u] $]$.

One, (8a), or both, (8b), members of a compound, or even a phrase composed of an adjective and a noun, may be diminutivized. Some of these diminutive forms are only used together (in

\footnotetext{
${ }^{12}$ There are diminutive forms like [ilona] > [itsuf], which apparently match a template - tsuf. However, this name has other diminutive forms, among them [i|tsa]. So instead of positing an otherwise unprecedented -CVC template, we claim that the base of [its|uf] is [itsa].
} 
the present meaning [kovi], and neither [ør|i], nor [har|i] occur on their own). Apparently, with names this is not a common possibility, we have found a single example, (8c).
Diminutive compounds
a. [bara:t-nø:] 'girlfriend' > [bar|i-nø:] 'girl friend (only of a woman)'

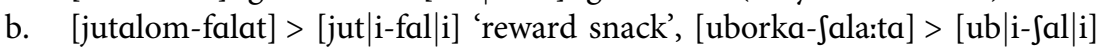
'cucumber salad', [kova:sof uborka] $>$ [kov|i ub|i] 'leavened cucumber', [ørøk harag] $>$ [ør $\mid$ i har $\mid \mathrm{i}]$ 'eternal resentment'
c. [anna-ma:rija] $>$ [anna-mar $\mid \mathrm{i}]$

There is a small set of monosyllabic diminutives. This is most common with phatic elements, as in (9a), and some common nouns, (9b), especially among specialists, but rather rare with given names, (9d). ${ }^{13}$ We are uncertain if the compounds in (9c) belong here at all. We will ignore this set in the present discussion.
Monosyllabic diminutives
a. [botfa:nat] $>$ [botf] 'excuse me', [køsønøm] $>$ [køs] 'thank you', [okfi] > [okf] 'okay', [tfa:o: $>$ [tfa:] 'bye!'

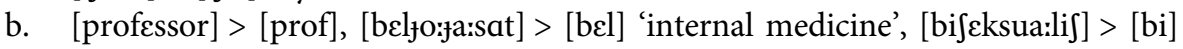 'bisexual'
c. [matematika-fizika] $>$ [mat-fiz] 'mathematics-physics', [sa:mi:ta:-texnika] >

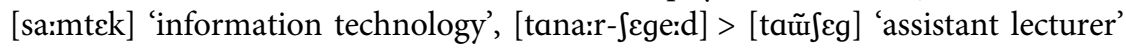
d. [zuzanna] $>[3 \mathrm{u}]$

\subsection{Templates containing [i]}

The most common template vowel is [i]. In the most common case this vowel is not accompanied by any consonant. This template is represented by the formula $-\mathbf{i}$. The other templates containing [i] are $-\mathbf{t s i},-\mathbf{j i},-\mathbf{t} \mathbf{i},-\mathbf{s i},-\mathbf{3 i}$, and $-\mathbf{z i}$.

6.1.1. The template $-\mathrm{i}$. We provide some examples of this template in (10).
Diminutives in [i]
a. $\left[\int y n\right]>\left[\int y n \mid i\right]$ 'hedgehog', $[$ tsomb $]>[$ tsomb $\mid \mathrm{i}]$ 'thigh', $\left[\operatorname{tap} \int\right]>\left[\operatorname{tap} \int \mid \mathrm{i}\right]$ 'applause'
b. [fø:nøk] $>$ [fø:n|i] 'chief, [dagatt] $>$ [dag|i] 'fat', [lo:verfen] $>$ [lov|i] 'horse race', [køsønøm] $>[\mathrm{køs} \mid \mathrm{i}]$ 'thank you', [bydø $]>[$ byd $\mid \mathrm{i}]$ 'stinky'

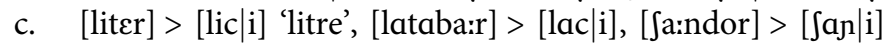
d. [ma:rta] $>$ [ma:rt $\mid \mathrm{i}]$, [burgona] $>$ [burg $\mid \mathrm{i}]$ 'potato', [izgalma $]>$ [izg $\mid \mathrm{i}]$ 'exciting'
e. $[$ børtøn] $>$ [bør|i] 'prison', [gergej] > [ger|i], [mozgo:ke:psi:nha:z] $>$ [moz|i] 'cinema'
f. [tcknø: $]]>[$ tck $\mid \mathrm{i}]$ 'turtle', [a:gne $\left.\int\right]>[\mathrm{a}: \mathrm{g} \mid \mathrm{i}]$

\footnotetext{
${ }^{13}$ Unlike in English, where it is very common: Susan $>$ Sue, Joseph > Joe, Peter $>$ Pete, Pamela > Pam, etc.
} 
Monosyllabic bases are unaffected by diminutive formation: in this case the process cannot be distinguished from regular additive suffixation, (10a). Any base that is longer is subject to truncation, which leaves behind a single vowel in the base. If there is a single consonant between the first two vowels of the base, it usually remains in the diminutive form, (10b). Some apparent exceptions include [h] and [j], as shown in (11).

\section{Consonant changes}

a. $[$ miha: $]>[$ mif $\mid \mathrm{i}],[$ ra:hel $]>[$ ra $\mid \mathrm{i}],[$ riha:rd $]>[$ rit $f \mid \mathrm{i}]$
b. $[$ lajof $]>[$ lal $\mid \mathrm{i}]$

The diminutives of names with [h] may be based on loan versions of these names (cf. French

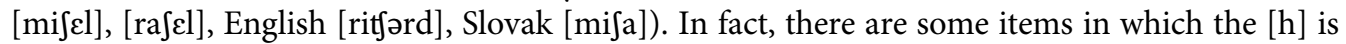
retained: [johanna] > [joh|i], [tihame:r] > [tih $\mid \mathrm{i}]$, [pihene: $\left.\int\right]>[$ pih $\mid \mathrm{i}]$ 'nap', [t]ih $\mid \mathrm{i}$ puh $\left.\mid \mathrm{i}\right]$ 'trashing. ${ }^{14}$ There also exist diminutive forms ending in [ji] ([kajeta:n] > [kaj|i], [aja:nde:k] > [aj|i] 'gift'), so the apparent substitution of [lali] for the rare diminutive form [laji] must have another explanation, to which we return in $\$ 7$.

As we will also see in $\$ \$ 6.2$ and 6.3 , the last consonant of the truncated base may turn into a palatal consonant. This is common before [a] and [o], and much rarer before [i], $(10 \mathrm{c}),[\mathrm{u}]$, (24e), and $[\varepsilon],(26 \mathrm{~b})$. A palatal consonant often occurs before [i] though, if it was already present

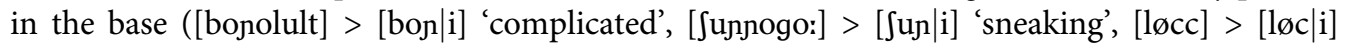

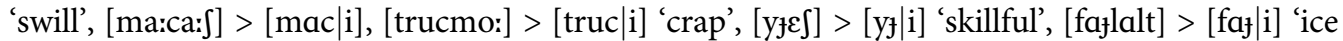

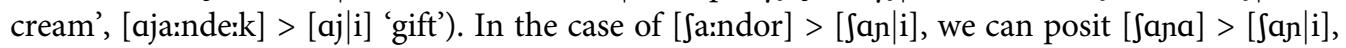
i.e., that its base is the $-\mathbf{a}$ diminutive form, in which palatalization is common. The form [maji], which is used as a diminutive of [magdolna], [margit], and [ma:rija], but is phonologically unexpected for any of them.

Bases containing a consonant cluster after their first vowel show divergent behaviour. As we show in (10d) and (10e), the same cluster may or may not be simplified. Homorganic nasal plosive clusters are practically never simplified (we have come across very few and not very

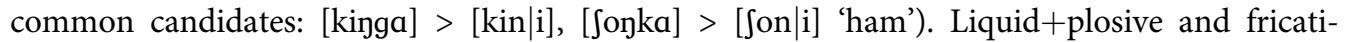
ve+plosive clusters, as well as geminates are more variable: the same name may exemplify both simplification and its absence ([zolta:n] $>$ [zol|i]/[zolt $\mid \mathrm{i}],[$ zolt $]>[$ zol $\mid \mathrm{i}] /[$ zolt $\mid \mathrm{i}],[$ otto: $]>[$ ott $\mid \mathrm{i}] /$ [ot $\mid \mathrm{i}]$ ). Nonhomorganic plosive + plosive clusters are more often simplified ([doktor] $>$ [dok $\mid \mathrm{i}]$ 'doctor', [zatfko:] > [zatf|i] 'sack') than not ([magdolna] $>$ [magd|i], [dikta:tor] > [dikt|i] ${ }^{15}$ 'dictator'). Earlier analyses that try to predict what happens to these clusters (Vago 1980; van de Weijer 1989) are based on very little data (only given names) and make empirically false predictions. They make reference to possible syllable- or word-final clusters. One problem is that the status of some clusters is dubious (for example, word-final [rb] occurs in two items, [scrb] 'Serbian' and [sorb] 'Sorbian'), and it is not clear if this should be taken to exist or not. More importantly, such an analysis is categorical and cannot predict the variation demonstrated above. In fact, we find both patterns with [rb], too: [borba:la] > [bor|i], [norbert] > [norb|i].

\footnotetext{
${ }^{14}$ The base of [t $\mathrm{fihi}$ is an obsolete verb meaning 'swish'. Possible bases of [puhi] are still in use: [puha] 'soft', [puhi:t] 'soften'.

${ }^{15}$ http://www.ahetedik.hu/kategoriak/versek/item/162-julius-ceasar.html
} 
What is more, even plosive+liquid clusters are found in diminutives of this category, although they are not possible word or syllable finally $([\operatorname{adrij} \varepsilon n]>[\operatorname{adr} \mid \mathrm{i}]$, [bodrof] $>$ [bodr $\mid \mathrm{i}]$, [patri:tsija] $>$ [patr $\mid \mathrm{i}] \sim[$ pat $\mid \mathrm{i}]) .^{16}$

While in many cases the vowel of the base remains unchanged, we find both shortening, (12a), and lengthening, (12b), of this vowel in [i]-diminutives.
Vowel length alternations
a. [ja:nof] $>$ [jan|i], [ma:rija] $>$ [mar|i], [ba:ra:n] $>$ [bar $\mid \mathrm{i}]$ 'lamb', [pe:ter] $>$ [pet $\mid \mathrm{i}]$, [li:dija] $>$ [lid $\mid \mathrm{i}]$, [ti:mea] $>$ [tim|i], [ju:lija] $>$ [jul|i], [hu: $]$ ] $>$ [huf $\mid \mathrm{i}]$ 'meat', [ro:za] $>[\mathrm{roz} \mid \mathrm{i}]^{17}$
b. $\quad[$ bencdek $]>[$ be:n $\mid \mathrm{i}],[$ dorocca $]>[$ do:r $\mid \mathrm{i}],[$ farolta $]>[$ sa:r $\mid \mathrm{i}]$

In some diminutive forms we find not [i], but [if]: the two endings appear to be free variants ([mari] $>$ [marif], [juli] > [julif]). However, this is the exception, in most cases the two forms are not interchangeable ([jani], but ${ }^{*}\left[\right.$ janif]; [hufi], but ${ }^{*}[\mathrm{hu} \mathrm{u} \mathrm{i} f]$ ). Furthermore, while the consonant cluster is simplified before [i] in [andra: $\left.\int\right]>[(\mathrm{b}) \text { and } \mid \mathrm{i}]^{18}$ ("[andri]), it is not in [andr|if] (*[andif]). Therefore - $\mathbf{i}$ and $-\mathbf{i} \int$ must be treated as two different templates, not as variants of each other.

The only phonotactic restriction that appears to hold for the $-\mathbf{i}$ template is that the template vowel may not follow a vowel. Thus bases containing hiatus after their first vowel do not have diminutives conforming to this template, they select other templates: [bea]/[bea:ta] $>{ }^{*}[\mathrm{~b} \varepsilon \mid \mathrm{i}]$ $([\mathrm{b} \varepsilon \mid \mathrm{u}]]),[$ noe:mi $]>{ }^{*}[$ no $\mid \mathrm{i}]([$ no: $\mid$ tsi $])$.

6.1.2. The templates $-\mathrm{tsi},-\int \mathbf{i},-\mathbf{t} \mathbf{i},-\mathbf{s i},-3 \mathbf{i}$, and $-\mathbf{z i}$. There are also templates with [i] that contain a consonant before the templatic vowel. This consonant is one of the four voiceless sibilants, $[\mathrm{s}],[\mathrm{s}],[\mathrm{ts}],[\mathrm{t}]$, and marginally also voiced [3] and [z]. Since we do not parse diminutive forms into morphs, the categorization is not always obvious. For example, [bolfEvik] > [bolfi] 'bolshevik' could be analysed either as the truncated base [bolf-] in the diminutive template $-\mathbf{i}$, or as the truncated base [bol-] in the diminutive template $-\int \mathbf{i}$. But since (i) the base contains [S] and (ii) we do not find any other diminutive form ending in [-1 $\mathrm{i}]$, here the first analysis is more plausible. In fact, the diminutive forms mentioned in (11a) can also be analysed as examples of the $-\int \mathbf{i}$ and $-\mathbf{t} \mathbf{j} \mathbf{i}$ templates. It is important to see that these decisions do not have to be made at all if we do not split diminutive forms into morphemes. A given phonological string may simultaneously fit into multiple templates. So [batsiluf] $>$ [batsi] 'bacillus' or [sotsijalifta] $>$ [sotsi] 'socialist' fit both $-\mathbf{i}$ and - tsi, that is, they

\footnotetext{
${ }^{16}$ German diminutives are rather different in this respect, cf. Itô \& Mester (1997); more on the stem-final clusters in Hungarian in Rebrus \& Szigetvári (2020).

${ }^{17} \mathrm{cf}$. the alternative forms of the name without shortening: [ro:3a] $>$ [ro:3|i]. One may propose that [rozi] is a diminutive of [roza:lija]. Also note that even length alternations may vary: [ma:rija] > [mar $\mid \mathrm{i}] /[$ ma:r $\mid \mathrm{i}]$, [pe:ter] $>$ [pet $\mid \mathrm{i}] /[$ pe:t $\mid \mathrm{i}]$, $[$ benedek] > [ben $\mid \mathrm{i}] /[$ be:n|i] .

${ }^{18}$ The source of the initial labial is a reduplication process common in child language in which a labial occlusive, [p], [b], or $[\mathrm{m}]$, is added to the second item (or if the stem begins with a labial, it is deleted in the first part): [andi bandi], [ifti pifti] 'tiny', [tuci muci] 'feckless' (Patay 2019; Sóskuthy \& Rácz 2020), cf. English itsy-bitsy.
} 
can be both [bats $\mid \mathrm{i}] /[$ sots $\mid \mathrm{i}]$ and $[\mathrm{ba} \mid \mathrm{tsi}] /[$ so $\mid$ tsi] at the same time. In (13) we only list items where the base does not contain [ts].

$$
\begin{aligned}
& \text {-tsi diminutives } \\
& \text { a. [nø:] }>[\mathrm{n} ø: \mid \text { tsi] 'woman' } \\
& \text { b. [motor }]>[\text { mo } \mid \text { tsi }] \text { 'motorbike', [føldrajz }]>[\text { fø } \mid \text { tsi }] \text { 'geography', [fodbal }]>[\text { fo } \mid \text { tsi }] \\
& \text { 'soccer', [ruha] }>\text { [ru|tsi] 'clothes', [3ido:] }>\text { [3i|tsi] 'Jew', [paripa }{ }^{19}>[\mathrm{pa} \mid \text { tsi] } \\
& \text { 'horse', [borju] }>\text { [bo|tsi] 'calf, [nadra:g] }>\text { [na } \mid \text { tsi] 'trousers', [frife } \delta]>[\text { fri } \mid \text { tsi], }
\end{aligned}
$$

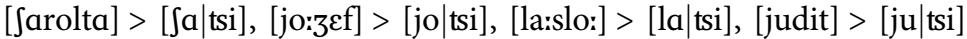

$$
\begin{aligned}
& \text { c. } \quad[\text { anna }]>[\text { an } \mid \text { tsi], [jenø: }]>\text { [jen } \mid \text { tsi], [ødøn] }>\text { [døn } \mid \text { tsi }] \text {, [be:la] }>[\text { be:l } \mid \text { tsi }] \text {, } \\
& \text { [bertalan }]>[\text { ber } \mid \text { tsi }] \text {, [dorina }]>[\text { dor } \mid \text { tsi }] \\
& \text { d. [be:la] }>\text { [be: } \mid \text { tsi], [norbert] }>\text { [no } \mid \text { tsi }] \\
& \text { e. [noe:mi] }>\text { [no:|tsi], [lø:rints] }>\text { [lo: } \mid \text { tsi }] \\
& \text { f. }[\mathrm{ana}]>[\mathrm{an} \mid \text { utsi] 'mother', [apa] }>\text { [ap } \mid \text { utsi] 'father', [mama] }>[\mathrm{mam} \mid \text { utsi] 'mum', } \\
& \text { [baba] }>\text { [bab } \mid \text { utsi] 'baby', [be:la] }>\text { [be:l|utsi], [t } \mathrm{aba}]>[\text { tfab } \mid \text { utsi], [emma] }> \\
& \text { [cmm|utsi], [kinga] > [king } \mid \text { utsi], [link] > [link } \mid \text { o:tsi] 'fink' }
\end{aligned}
$$

The examples in (13) show that most consonants after the first vowel of the base are trimmed, (13a), unless they form a relatively unmarked cluster with [ts]: [nts], [rts], [lts], (13c). But in some items even $[\mathrm{r}]$ and $[\mathrm{l}]$ is trimmed, (13d). Here too we find cases of vowel quantity alternations in both directions: [no:tsi] in (13e), [jotsi] in (13b), as well as an unexpected vowel quality alternation, [ø:]-[o:], in (13e). Another surprising property of this diminutive ending is that it also features in a trisyllabic template, (13f). One could assume that some of these items are a diminutive of a diminutive ([anu], [apu], [be:lu] exist independently as diminutive forms), but the shorter form of the others does not exist. ${ }^{20}$

We have already seen that there are diminutive forms ending in [ji]. Those that do not contain [S] in their base fit only the - $\mathbf{- i}$ template. We have also seen that there are no diminutive forms ending in [1]i]. As a matter of fact, we have only found examples for this template in which there is a noncoronal plosive before [S], we list them in (14). ${ }^{21}$

$$
\begin{aligned}
& \text { - } \mathbf{\text { i diminutives }} \\
& \text { a. [akkumula:tor] }>\text { [ak } \mid \text { Si] 'battery', ? > [buk } \mid \text { Si] 'head', [dokumentum] }>\left[\operatorname{dok} \mid \int \mathrm{ji}\right] \\
& \text { 'document', [jogofi:tva:n] > [jok } \mid \text { Si] 'driving licence', [oke:] }>\text { [ok } \mid \text { Si] 'okay', [vak] > } \\
& \text { [vak } \mid \text { ji] 'blind', [kaka] }>\text { [kak } \mid \text { si] 'poop' } \\
& \text { b. [biboldo: }]^{22}>\text { [bip } \mid \text { Si] 'Jewish', [libera:lif] }>\text { [lip } \mid \text { Si] 'liberal', [popo:] > [pop } \mid \text { Si] 'bum' }
\end{aligned}
$$

\footnotetext{
${ }^{19} \mathrm{TESz}$ claims that the base of [patsi] is unknown. Semantically [paripa] is an obvious candidate, but Janurik (2009) identifies [pata] 'hoof as its base.

${ }^{20}$ The diminutive [kuca] > [kuc|uli] 'dog' is unique both in being trisyllabic and in its ending.

${ }^{21}$ According to TESz, the base of the diminutive form [hap $\mathrm{i}$ ] 'guy' is possibly [haver] 'pal', in which the last consonant of the base is strengthened to a plosive, strengthening our suspicion that having a plosive before the [ $\left.\int\right]$ is a requirement of this template.

${ }^{22}$ From Romani [biboldo] 'Jewish, lit. unbaptized'.
} 
The - $\mathbf{t} \mathbf{i}$ template is less strict than any of the other templates containing [i]. It forms a consonant cluster with both a homorganic and nonhomorganic nasal, (15a) and (15e), with approximants, (15b-d), and even with plosives and fricatives, (15f-g), creating clusters unprecedented within a morpheme. This tolerance of pre- $[\mathrm{t}]$ consonants in the $-\mathbf{t} \mathbf{t} \mathbf{i}$ template must be the reason why we hardly find cases where [tfi] follows a vowel. ${ }^{23}(15 \mathrm{~h})$ is a unique case of metathesis in the base.

\section{-tyi diminutives}

a. [ja:nof] $>$ [jan $\mid \mathrm{t} \mathrm{f}]$, [unalma $\left.\int\right]>$ [un $\left.\mid \mathrm{t} \mathrm{fi}\right]$ 'boring', [finom] $>$ [fin $\left.\mid \mathrm{t} \mathrm{fi}\right]$ 'delicious'

b. [ka:roj] > [kar $\mid \mathrm{ti}]$, [ma:rija] $>$ [mar $\mid \mathrm{ti}]$, [tere:z] $>$ [ter $\mid \mathrm{t} \mathrm{j}]$, [tu:r] 'dig' > [tur $\mid \mathrm{tji}]$ 'turned up nose'

c. $[$ ju:lija] $>$ [jul|tfi], [pulo:ver] $>$ [pul $\mid \mathrm{t} \mathrm{j}]$ 'pullover', [dolla:r] $>[$ dol $\mid \mathrm{t} \mathrm{f}]$ 'dollar', [balaton] $>[$ bal $\mid \mathrm{tg} \mathrm{i}]$

d. [haj] > [haj|tfi] 'hey!, sleep', [kaja] > [kaj|tfi] 'food', [lajof] > [laj $\mid \mathrm{t} \mathrm{fi}]$

e. $\quad[$ amerikaji] $>[\mathrm{am} \mid \mathrm{t} \mathrm{fi}]$ 'American', [komoj] $>$ [kom $\mid \mathrm{t} \mathrm{fi}]$ 'serious(ly)', [komunifta] $>$ [kom $\mid \mathrm{t} \mathrm{j}]$ 'communist', [duma] $>$ [dum $\mid \mathrm{t} \mathrm{j}]$ ' 'blurb'

f. $\quad$ [japa:n] $>$ [jap $\mid \mathrm{t} \mathrm{fi}]$ 'Japanese', [repylø] $>$ [rep $\mid \mathrm{t} \mathrm{fi}]$ 'airplane', [libera:lif] $>$ [lip $\mid \mathrm{t} \mathrm{j} \mathrm{i}]$ 'liberal', [sopa: $\left.\int\right]>[$ sop $\mid t f i]$ 'suck', [super] $>$ [sup $\left.\mid \mathrm{t} \mathrm{i}\right]$ 'super', [yditø:] $>$ [yt $\left.\mid \mathrm{t} \mathrm{fi}\right] /$ $[\mathrm{yt} f \mid \mathrm{t} \mathrm{i}]$ 'soft drink'

g. $\quad[\mathrm{k} ø$ øøn $ø \mathrm{~m}]>[\mathrm{køs} \mid \mathrm{t} \mathrm{fi}]$ 'thank you', [pofa] $>$ [pof $\mid \mathrm{t} \mathrm{f}]$ 'mouth', [laf $\mid \mathrm{t} \mathrm{j}]$ 'love'

h. [forint $]>[$ fron $\mid t$ fi] 'Forint'

Unlike - $\mathbf{t} \mathbf{f i}$ diminutives, $\mathbf{-} \mathbf{s i}$ diminutives are very strict phonotactically and, as a result, there are much fewer examples. The [1] of the base is trimmed before [s] in this template, (16a). On the other hand, not only [j], (16b), but even the pre-voiceless version of $[\mathrm{b}],[\mathrm{p}]$, as well as $[\mathrm{k}]$ remains, (16c). In this latter respect $-\mathbf{s i}$ is similar to $-\int \mathbf{i}$.

\section{-si diminutives}

a. [nu:l] $>$ [nu|si] 'rabbit', [fula] $>$ [fu|si]

b. $[\mathrm{t} \mathrm{faj}]>[\mathrm{t} \mathrm{faj} \mid \mathrm{si}]$ 'girl'

c. [babett] $>$ [bap $\mid$ si], [t $\left.\int \mathrm{aba}\right]>$ [tfap $\mid$ si], [ga:bor] $/$ gabrijella] $>$ [gap $\mid$ si], [ka:bi:to:ser] $>$ [ka:p|si] 'drug', [łakorlat] > [jak $\mid$ si] 'exercise', [oke: $>$ [ok $\mid$ si] 'okay'

Finally, some items end in $[-3 i]$ and $[-z i]$.

\section{$-\mathbf{3 i}$ and $-\mathbf{z i}$ diminutives}

a. [kap] 'capture' > $[\mathrm{kab} \mid 3 \mathrm{i}]$ 'greedy', [tøm] 'pad'> [tøm $\mid 3 \mathrm{i}]$ 'squab'

b. [nyzge: $\left.\int\right]>$ [nyzi] 'moseying', [dø:zøle: $\left.\int\right]>$ [dø:zi] 'feasting', [habzola: $]>$ [habzi] 'devour'

\footnotetext{
${ }^{23}$ The dimutives ending in a vowel $+[\mathrm{t} \mathrm{i}]$ have $[\mathrm{t}]$ in their base, so they also conform to the -i template: [botfa:nat] > [bot $f \mid \mathrm{i}]$ 'excuse me', [tfatfog] 'prattle' > [tfatf|i] 'obtuse, donkey', [øtf(:)] > [øtf|i] 'younger brother', [vatfora] > [vat $\mid \mathrm{i}]$ 'supper'. We have discussed [riha:rd] > [ritf|i] above. The etymology of [ba:ti] 'uncle' is not obvious, it is clearly connected to [ba:c(c)] 'older brother', but there are competing hypotheses about the source of the [t $\mathrm{g}]$.
} 
c. [ga: $\int$ pa:r] $>$ [gazi], [bala:3] > [bazi], [mo:ze $\left.\int\right]>$ [mo:3i], [tere:zija] $>$ [tre:3i], [disko:] > [dizi] 'disco'

d. [lakodalom] $>$ [lag $\mid$ zi $]$ 'nuptials', $[$ zita $]>$ [zizi $]$

This is a rather varied set. In (17a) we see a verbal base that does not contain [3]. ${ }^{24}$ The adjectives they are paired with probably exemplify a $-3 \mathbf{i}$ template. The pairs in (17b) satisfy both this and the general $-\mathbf{i}$ template. In (17c) we have names which contain close phonetic relatives of [3], [S], [s], [z], or [3] itself, as in [bazi], however, this item does not satisfy the $-\mathbf{i}$ template either, because it does not contain a contiguous portion of the base.

(17d) again seems to exemplify a valid diminutive template, - zi. However, we will provide an alternative analysis for [zizi] in $\$ 7$, leaving a single item, [lagzi], as an example of this template.

6.1.3. Another trisyllabic template. Besides the trisyllabic template ending in [-tsi], there also seems to be one ending in [-ri]. Instances are mostly adjectives. The examples in (18a-b) all have a verbal base which contains the $[\mathrm{r}]$. The two adjectives in (18c) fit the template, but have no $[r]$ in their base.
Trisyllabic template ending in [-ri]
a. [zugori:t] 'to shrink' > [zugori] 'miser', [viforog] 'to sneer' $>$ [vifori] 'sneering', [vitforog] 'to snarl' > [vitfori] 'snarling', [tfyt $ø$ riit] 'to purse' > [tfytføri] 'pursing', [kupkorodik] 'to frizzle' $>$ [kunkori] 'curly', [kukore:kol] 'to crow' $>$ [kukori] a roosters name
b. [be-sar] 'to shit in (one's pants)' > [besari] 'candy-assed', [fatfar] 'to wring' > [fatfari] 'miser', [fasa-ra:go:] 'penis chewer' > [fasari] 'miser'25
c. [pinduri] 'small', [pitsi] $>$ [pitsuri] 'small'

\subsection{Templates containing [a]}

Unlike diminutives ending in [i], the diminutive template - $\mathbf{a}$ imposes a restriction on the first syllable, it must be light. ${ }^{26}$ This means that a long vowel in the base is shortened, (19b, e), and a consonant cluster is trimmed, (19c, f). ${ }^{27}$ Another property of this class is the potential palatalization of the consonant before [a], (19d-f). We have only found examples of $[\mathrm{t}] \rightarrow[\mathrm{c}],[\mathrm{n}] /[\mathrm{m}] \rightarrow[\mathrm{n}]$, and $[\mathrm{l}] \rightarrow[\mathrm{j}]$ (recall, "palatalized $[\mathrm{l}]$ ” is $[\mathrm{j}]$ ), not for $[\mathrm{d}] \rightarrow[\mathrm{j}]$.

\footnotetext{
${ }^{24}$ Note that the bases in (17a) are verbal, the corresponding diminutives are adjectives. We could posit adjectival bases (participles) as well: [kapo:] 'capturing', [tømøtt] 'padded'.

${ }^{25} \mathrm{TESz}$ claims that [fasari] may also be seen as a contamination of [sar-fatfar-o:] 'shit wringer'.

${ }^{26}$ The rare diminutive $[\varepsilon r 3 e: b \varepsilon t]>[\varepsilon r 3 a]$ is an exception here.

${ }^{27}$ The pair [puntsi] 'cunt' > [putsa] 'cunt, groin' seems to belong here. In fact, the first word is a loan from German slang [puntsə] id., the latter from Rumanian [putsə] 'child's genitals'. They match the templates though.
} 
This kind of palatalization is different from what we see in regular additive morphology. There it is a $[j]$ segment in the suffix that palatalizes the preceding dental consonant, resulting in a palatal geminate after a vowel, ${ }^{28}(4 \mathrm{c})$. Diminutive palatalization never results in a geminate, therefore we do not posit a - ja template. In want of a better formula, we will represent this as $-^{\mathbf{j}} \mathbf{a}$.

\section{-a diminutives}

a. $[$ rrika] $>[\varepsilon r \mid a],[\varepsilon t \varepsilon l k a]>[\varepsilon t \mid a],[$ ilona $]>[$ il $\mid a],[k a t a l i n]>[$ kat $\mid \mathbf{a}],[$ bonolult $]>$

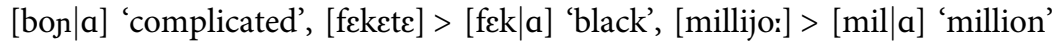

b. $[$ ma:rija $]>[\operatorname{mar} \mid \mathrm{a}]$

c. $[$ borba:la] $>[$ bor $\mid \mathrm{a}]$, [dolgozat $]>[$ dog $\mid \mathrm{a}]$ 'test', [scruus] $>[$ [sev $\mid \mathrm{a}]$ 'hello'

d. $[$ benzin $]>[\mathrm{b} \varepsilon \mathbf{n} \mid \mathrm{a}]$ 'benzine', $[\operatorname{sendvitf}]>[\operatorname{sen} \mid \mathrm{a}]$ 'sandwich', $[\operatorname{seme:t}]>[\operatorname{sen} \mid \mathbf{a}]$ 'sleaze'

e. $\quad[p a: 1]>[p a j \mid a],[p e: t e r]>[p \varepsilon c \mid a],\left[\int a: n d o r\right]>\left[\int a n \mid a\right],[$ to:t $]>[$ toc $\mid \mathbf{a}]$

f. $[$ viktor $]>[$ vic $\mid \mathrm{a}]$, [zolta:n] $>[$ zoc $\mid \mathrm{a}]$

g. $\quad[$ bitsikli] $>[$ bits $\mid$ aj] 'bicycle', [repylø] $>$ [rebzaj] 'plane'

h. $\left[\int a p k a\right] /\left[\int i p k a\right]>\left[\int a c a k\right] /\left[\int i c a k\right]$ 'cap'

The items in $(19 \mathrm{~g})$ and $(19 \mathrm{~h})$ are difficult to fit into our system of templates. The final [j] only occurs in these two diminutive forms. ${ }^{29}$ The [z] of [rrbzaj] may be enforced by the word [zaj] 'noise'. Template-final [k] is also unprecedented apart from the two variant diminutives [Sicak] and [jacak].

Like diminutives in [i], diminutives in [a] also have templates in which a consonant precedes the template vowel. In the - tsa template we have found mostly names, other items that could qualify semantically do not have a base ([tsitsa] 'pussycat', [tsotsa] 'piggy'). Many of these names are disyllabic, (20a), hence they fit among all other disyllabic templates discussed here. However, there is also a trisyllabic set, which contains exclusively female names, ${ }^{30}(20 \mathrm{~b})$. We could claim that these are diminutives of diminutives (like some items in (13f) above), [a:gi], [bogi], [dalmi], etc. are all diminutive names. In this case [-tsa] could be categorized as an additive suffix. In fact, these forms are on the borderline of additive and templatic diminutive formation. While all these forms are trisyllabic, which follows from the fact that their stem is a disyllabic $-\mathbf{i}$ diminutive, the only front stem, [e:vi], usually occurs with the nonharmonizing ending [-tsa], which is templatic behaviour, the alternative form [e:vi-tse] also exists. The harmonicity of the ending in the latter form hints at additive suffixation, as in the case of the additive diminutive suffix in [malats-ka] 'pig-DIM', [a:gi-ka] vs. [ $\varepsilon g e: r-k \varepsilon]$ 'mouse-DIM', [e:vi-ks].

\footnotetext{
${ }^{28}$ Recall, gemination does not occur only after a consonant: [pont] $+[\mathrm{ja}]$ is [ponca] 'point-3sG.Poss', [ost] $+[\mathrm{ja}]$ is [osca] 'divide-3SG.DEF_OBJ'.

${ }^{29}$ Bárczi identifies the German suffix [-ai] as the source of this ending and provides some further examples, which do not exist in present-day Hungarian (1931-1932, 90).

${ }^{30}$ There is also a common noun in this set containing an augmented bound stem: [far(o)k] 'tail' > [farkintsa].
} 
(20)

-tsa diminutives

a. $\quad[$ ilona $]>[\mathrm{i} \mid \mathrm{tsa}],[\mathrm{ma}: \mathrm{rija}]>[\mathrm{ma} \mid \mathrm{tsa}],[$ tere:z $]>[\mathrm{t} \varepsilon \mid \mathrm{tsa}],[$ la:slo: $]>[$ la $\mid$ tsa $],[$ Jarolta] $>$ [ $a \mid$ tsa], [e:vi] $>$ [vi|tsa], [li:vija] $>$ [vi|tsa], [a:gi] $>$ [gi |tsa], [olgi] $>$ [gi|tsa]

b. [a:gnef] $>$ [a:g $\mid$ itsa], [bogla:rka] $>$ [bog $\mid$ itsa], [dalma] $>$ [dalm $\mid$ itsa], [e:va] $>$ [e:v|itsa], [gabrijella] $>$ [gab|itsa], [katalin] $>$ [kat $\mid$ itsa], [kla:ra] $>$ [kla:r $\mid$ itsa], [ma:rija $]>[$ mar $\mid$ itsa $]$, olga $]>[$ olg $\mid$ itsa $]$

It is not only [ts], but also [t] and [s], but not [s], [3], or [z] that occur before [a] in diminutive templates. On the other hand, we find $[\mathrm{k}]$ in this position, which could not accompany [i].

$$
\begin{aligned}
& \mathbf{- t} \mathbf{a} \mathbf{a},-\mathbf{s a} \text {, and }-\mathbf{k a} \text { diminutives } \\
& \text { a. }[\text { anna] }>\text { [an } \mid \mathrm{t} \mathrm{a}] \text {, [borba:la] }>\text { [bor } \mid \mathrm{t} \mathrm{a}] \text {, [ju:lija] }>\text { [jul } \mid \mathrm{t} \mathrm{a}] \text {, [ma:rija] }>[\text { mar } \mid \mathrm{t} a] \text {, } \\
& \text { [ra:ktfa:lnivalo: }]>[\mathrm{ra}: \mathrm{k} \mid \mathrm{t} \mathrm{fa}]^{31} \text { 'snack' } \\
& \text { b. } \quad[\text { oke: }]>\left[\mathrm{ok} \mid \int \mathrm{Ja}\right] \text { 'okay' } \\
& \text { c. }[\mathrm{t} \varepsilon r e: z]>[\mathrm{t} \varepsilon r \mid \mathrm{ka}],[\text { [ milija] }>\text { [mil } \mid \mathrm{ka}] \text {, [tscruza] }>\text { [tser } \mid \mathrm{ka}] \text {, [heroin] }>\text { [her } \mid \mathrm{ka}] \text { id., } \\
& \text { [ponc] }>\text { [poc|ka] 'carp', [tsitsa] }>\text { [tsits } \mid \mathrm{ka}] \text { as in [tsitskafark] 'yarrow (lit. cat's tail)' } \\
& \text { d. [ilona] }>\text { [ilon } \mid \mathrm{ka}],[\text { katalin] }>\text { [katip } \mid \mathrm{ka}], \text { [ueronika] }>\text { [ueronka], [atilla] }> \\
& \text { [atil|ka], [tse:dula] > [tse:dul|ka] 'tag', [tala:lkozo:] > [tala:lka] 'rendezvous', } \\
& \text { [siporka:z-] 'to sparkle'> [siporka] 'witty talk' }
\end{aligned}
$$

It is noteworthy, that [-ka] is homophonous with the back allomorph of the additive diminutive suffix $[-\mathrm{ka}] /[-\mathrm{k} \varepsilon]$ ([katalin-ka] vs. [cuclin-ke]). Yet it is different from it in two terms: it is at the end of a truncated base, so that the diminutive form is disyllabic, and it does not harmonize, it invariably has a back vowel (cf. [terka] vs. [tere:s-ke]). We do find nonnharmonizing vowels in regular additive suffixes, but these are neutral vowels, [i], [i:], and [e:], there are no regular suffixes containing nonalternating [a]. Likewise, we must analyse the endings of the two diminute forms [furi-ka] and [fur|ka] differently. In the first word it is the additive suffix

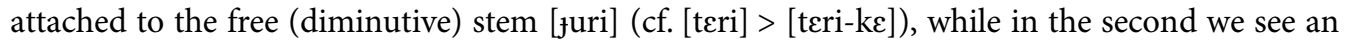
instance of the - $\mathbf{k a}$ diminutive template.

Here too we find a trisyllabic template, exemplified by the items in (21d). In fact, all of these diminutive forms have a consonant before [-ka], but this consonant is also present in the base. Yet the base is truncated in a way that is untypical of the vowel loss described in $\$ 4$.

\subsection{Templates containing [0]}

Short [o] (and to a lesser extent short [ø], but see $\$ 7$ ) does not occur word finally in Hungarian. As a result, we find long [o:] in diminutives whose template contains this vowel word finally, (22a). In a more limited set of diminutives, the template is consonant final. This consonant is

\footnotetext{
${ }^{31}$ [ra:ktfa] and [siporka] may also be analysed as cases of backformation: [-1] in [ra:ktfa:l] 'crunch' and [-z] in [siporka:z-] are the two productive verbalizing suffixes. ([ra:ktfa:lnivalo:] could be translated as 'crunchable(s)'.) Yet they certainly fit the relevant templates, too.
} 
either [s], (22b), or [k], (22c), the items in the latter set are archaic, but the correlation between the base and the diminutive form is rather obvious.

The -o:, -os, and -o:k templates

a. [tsitsa] $>$ [tsits $\mid$ o:] 'pussycat', [bitsikli] $>$ [bits $\mid$ o:] 'bicycle', [ba:c] $>$ [ba:c $\mid$ o:] 'older

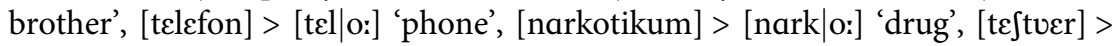

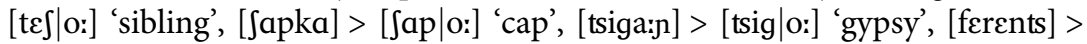
[fer $\mid$ o: $]$, [ja:nof] $>$ [jan $\mid$ o:], [katalin] > [kat $\mid$ o:], [margit] $>$ [marg $\mid$ o: $]$

b [filozo:fu]] $>$ [fil $\mid$ os] 'philosopher', [bijolo:gija] $>$ [bij $\mid$ os] 'biology (as a school subject)', [matfka] $>$ [matfk $\mid$ os] 'cat'

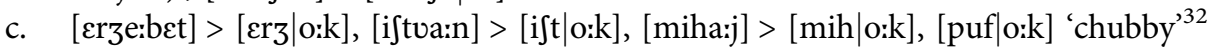

d. [gita:r] > [ gic|o:] 'guitar', [vintfester] > [vip $\mid$ o:] 'harddisk', [pintse] > [pin $\mid$ o:] 'cellar',

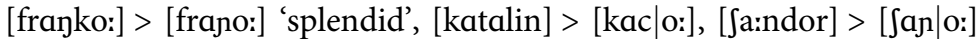

e. [ma:ca: $]>[$ mac $\mid$ o: $]$, [jo:c-pedago:gija] ${ }^{33}$ 'special education' $>$ [jof $\mid$ o: $]$ 'mentally retarded', [genлє $]>$ [gen|o:] 'scuzzbag'

f. [tarisna] > [taco:] 'bag', [letske] $>$ [leno:] 'homework', [girhe $\left.\int\right]>$ [girno:] 'meagre', [heroin] > [herno:] id., [klozett] > [kloco:] 'toilet', [be:na] > [be:ngo:] 'hapless', [mertse:des] > [merbo:] 'Mercedes'

Like in diminutive templates containing [a], we find items with a palatal consonant also before the template vowel [o:], $(22 \mathrm{~d}-\mathrm{e})$. In the second set, the palatal is present in the base too, but in the first set we only find it in the diminutive form. The diminutives in (22f) exhibit random consonant alternations. It must be noted that [herno:] is homonymous with the common term for 'caterpillar'.

The most common consonant occurring before templatic [o:] is [k], (23a), but [ts] and [J] also occur marginally, $(23 \mathrm{~b}-\mathrm{c})$.

The -ko:, -tso:, and - $\mathbf{s o :}$ templates

a. [lajof] $>$ [laj|ko:], [ferents] $>$ [fer|ko:], [ja:nof] $>$ [jan $\mid$ ko:], [sa:n] $>$ [sa:n|ko:] 'sledge', [tferesne] > [tfer|ko:] 'cherry', [fesylt $\left.\int \mathrm{e:g}\right]>$ [fes $\mid$ ko: 'tension', [milijo:] > [mil|ko:] 'million', [Jpetsija:lif] > [Spets|ko:] 'special', [prote:zif] > [prot|ko:] 'denture', [tetova:la: $\left.\int\right]>$ [tet|ko:] 'tattoo', [latsi]/[latsa] > [lats|ko:], [tfeslova:kija] > [tfes $\mid$ ko:] 'Czechoslovakia'34

b. $\quad[$ ferents $]>[\mathrm{f} \varepsilon \mid$ tso: $]$, [ke:gli] $>$ [ke|tso:] 'appartment', [nadra:g] $>$ [na|tso:] 'trousers'

c. $[\mathrm{muki}]>[\mathrm{muk} \mid \mathrm{So:}]$ 'guy', ${ }^{35}\left[\mathrm{utol} \int \mathrm{s}:\right]>\left[\mathrm{ut} \mid \int \mathrm{So}\right]^{36}(\rightarrow[\mathrm{utftfo:}])$ 'last'

\footnotetext{
${ }^{32}$ The base of this word is [pofa] 'face', but the connection is rather obscure. Also note the further diminutive form [pufi].

${ }^{33}$ The first stem in the compound [jo:c-pedago:gija] is the bound stem [jo:--], a backformation from the verb [jo:ji:t] 'heal'. This explains the voicing of $[\mathfrak{f}]$ in [jofo:]. Alternatively, this may be a reduplicative diminutive, cf. $\$ 7$.

${ }^{34}$ Although [ $\mathrm{t} \varepsilon \mathrm{sk}$ ] $]$ happens to be 'Czechia' in Czech (and Slovak), and thus it could be analysed as a loanword, in Hungarian [tfesko:] was mainly used for former Czechoslovakia, not Czechia.

${ }^{35}$ The archaic name [muki] is itself a diminutive of [nepomuk].

${ }^{36}$ The base of [utfo:] contains [S], so it may be an instantiation of the -o: template with unsual internal truncation.
} 
The items in $(23 b-c)$ show that this ending is also not harmonically variable. This is so because

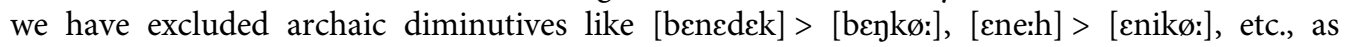
explained in $\$ 2$.

\subsection{Templates containing [u]}

Like in templates containing [i], those with [u] also may end in [J]. The words in (24a) could also be considered instances of clipping, but those in $(24 b-c)$ show that there does exist a diminutive template $-\mathbf{u}$. The diminutives in $(24 \mathrm{a}-\mathrm{b})$ do not end in $[\mathrm{u}]$, those in $(24 \mathrm{c})$ alternate, those in (24d) obligatorily end in [S], they only have a diminutive form in the $-\mathbf{u} \int$ template. The last consonant of the trimmed base may be palatalized before $[\mathrm{u}]$, like before $[\mathrm{a}]$ and $[\mathrm{o}],(24 \mathrm{e})$.

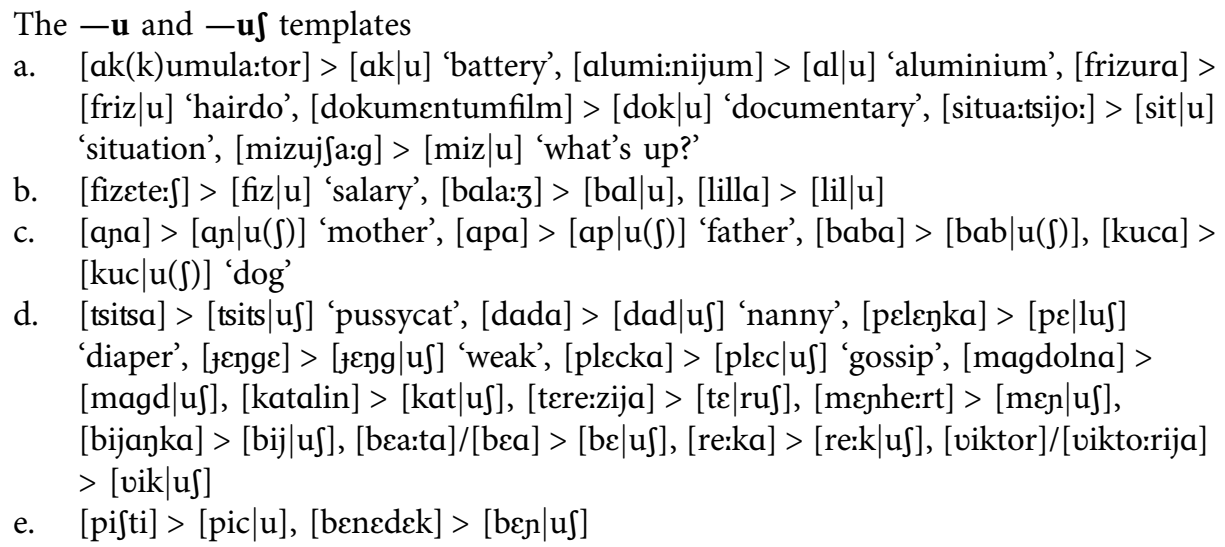

There is no clear evidence for any templatic consonant before $[\mathrm{u}]$. The candidates are listed in (25).

(25) Apparent templatic consonants before [u]
a. [hekuf] 'policeman'
b. [ilona] $>$ [itsu], [judit $]>$ [jutsuf]

However, the base of [hekuf], is obsolete, ${ }^{37}$ while both [itsu] and [jutsuf] may be associated with the diminutive forms [itsa], (20a), and [jutsi], (13b), respectively. If these analyses are right, there is little reason to assume that there exist templates - $\mathbf{k u} \mathbf{\int}, \mathbf{- t s u}$, or - tsuf.

\subsection{Templates containing $[\varepsilon]$}

While all other template vowels occur at the end of diminutive forms, $[\varepsilon]$ does not, it is always followed by a consonant, which may be [s], (26a-b), [k], (26c-d), or [r], (26e-f). We have found

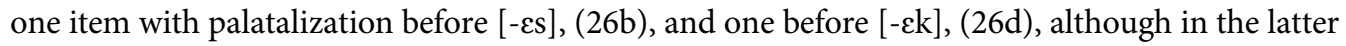

\footnotetext{
${ }^{37}$ The slang words [he:] 'police', [he:be] 'police station' (loans from German slang) were current at the beginning of the 20th century in Hungarian, but later went extinct.
} 
case the source of the palatalized consonant is unclear. The ending [- $\mathrm{ff}]$ in $(26 \mathrm{~g})$ is unprecedented, we suspect that this diminutive form is a loan.

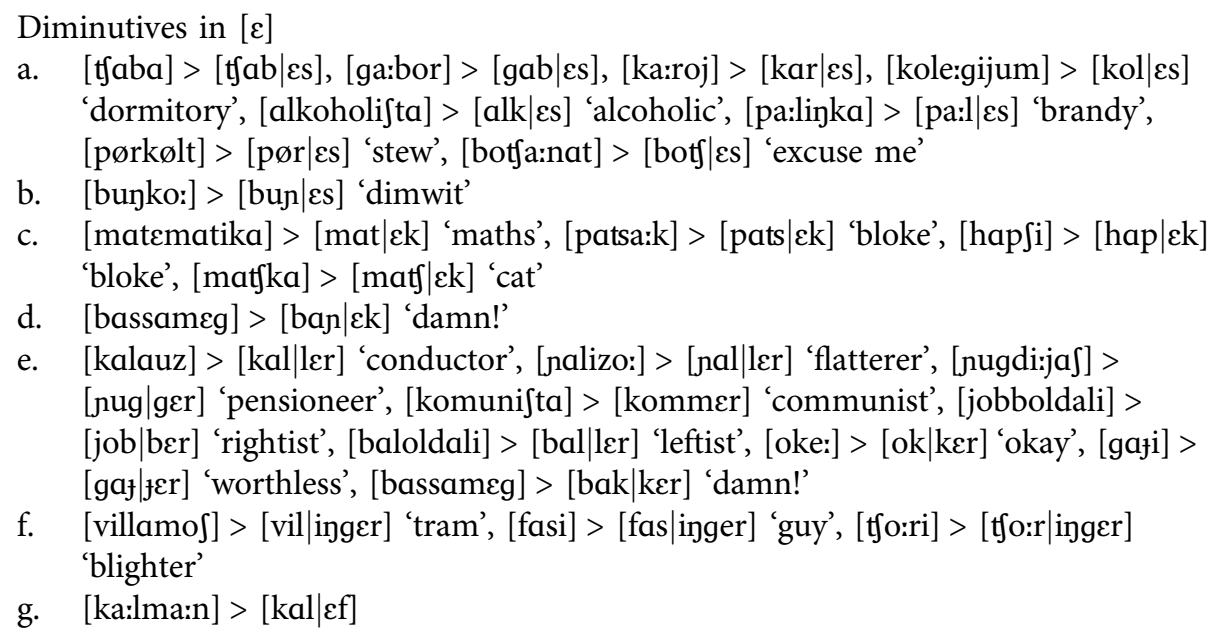

It is a unique feature of diminutives ending in [-er] that the consonant before the ending is geminated, hence we assign the formula - icr to this template. We could not identify the source of the [k] in [bakker]. We assume that this template imitates disyllabic German and English loanwords in which the consonant between the two vowels is also often geminated ([roller] 'scooter', [suetter] 'sweater', [trigger] 'trigger', [vekker] 'alarm clock', [koffer] 'trunk', [zitstser] 'opportunity', [Jtopper] 'stopwatch', etc., cf. Nádasdy 1989). Likewise, - $\mathbf{\varepsilon s}$ diminutives are phonologically similar to a set of Yiddish loanwords ([tso:res] 'misery', [matses] 'matzah', [pajes]

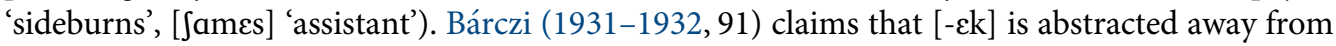
words of Slavic origin (more specifically, probably Slovak).

In a smaller set of words we find a trisyllabic template, -inger. This is less productive than -:er. The form [kalef], (26g), is unique in having the ending [-عf], we could not discover its provenance.

\subsection{Summary of disyllabic diminutive templates}

We summarize the disyllabic diminutive templates we have identified so far in (27). For the templates that are in parentheses we have only found one example. ${ }^{38}$ The $[\mathrm{j}]$ in superscript represents the palatalization of the consonant before the templatic vowel. We have seen that this is not a reflex of a consonant [j], but the representation is not meant to suggest an autosegmental analysis for this phenomenon. In this chart we ignore vowel length alternations in the stem.

\footnotetext{
${ }^{38}$ In this case we only considered diminutives in which the palatal or the [ $\left.\int\right]$ is not present in the base. So although [anuf] 'mother.DIM' or [tefo:] 'sibling.DIM' match the template $-{ }^{j} \mathbf{u} \int$ and $-\mathbf{S o}$ :, they are here taken to belong only to $-\mathbf{u} \int$ and -o:
} 
(27)

Disyllabic diminutive template endings

\begin{tabular}{|c|c|c|c|c|c|}
\hline & $-\mathrm{i}$ & $-a$ & -0 & $-\mathrm{u}$ & $-\varepsilon$ \\
\hline & $-\mathrm{i},-\mathrm{i} \int$ & $-a,(-a j)$ & -o:, 一os, -o:k & $-\mathrm{u},-\mathrm{u} \int$ & $\begin{array}{c}-\varepsilon s,-\varepsilon k,-: \varepsilon r, \\
(-\varepsilon f)\end{array}$ \\
\hline$j_{-}$ & $-^{\mathrm{j}_{\mathrm{i}}}$ & $--^{\mathrm{j}} \mathrm{a},\left(-^{\mathrm{j}} \mathrm{ak}\right)$ & $-{ }^{\mathrm{j}} \mathrm{O}:$ & $(-\mathrm{j} \mathrm{u}),\left(-{ }^{\mathrm{j}} \mathrm{u} \int\right)$ & $\left(-^{\mathrm{j}} \varepsilon s\right),\left(-^{\mathrm{j}} \varepsilon \mathrm{k}\right)$ \\
\hline$-k-$ & & $-\mathrm{ka}$ & -ko: & & \\
\hline- ts- & - tsi & -tsa & -tso: & & \\
\hline$-t 5-$ & $-\mathrm{t} \mathrm{i}$ & $-t \int a$ & & & \\
\hline$-\int-$ & $-\int \mathrm{i}$ & $\left(-\int a\right)$ & $\left(-\int \mathrm{o:}\right)$ & & \\
\hline$-\mathbf{s -}$ & $-\mathrm{si}$ & & & & \\
\hline$-3-$ & $-3^{i}$ & & & & \\
\hline$\underline{-\mathbf{z}-}$ & $(-\mathrm{zi})$ & & & & \\
\hline
\end{tabular}

Based on this chart, we can make the following generalizations:

1. Of the seven short vowels, five occur in diminutive templates, the two most marked ones, the front round vowels [y] and [ø], do not. We discuss the relevance of this gap in $₫ 8$. Long vowels are also not common in this function, the only exception is [o:], which is required by a phonotactic constraint against word-final short [o] in Hungarian.

2. All five templatic vowels may occur right after the truncated base. Palatalization of the base-final consonant is a possibility before all templatic vowels, but occurs only marginally before $[\mathrm{u}]$ and $[\varepsilon]$ (we have found a single example for each possibility), and less commonly before [i].

3. A consonant may follow the templatic vowel. This may be [S] after the high vowels [i] and $[\mathrm{u}]$, and $[\mathrm{s}]$ or $[\mathrm{k}]$ after mid $[\mathrm{o}]$ and $[\varepsilon]$. It may also be $[\mathrm{r}]$ in the "geminating" template -:er. The template vowel [a] may marginally be followed by $[\mathrm{j}]$ and $[\mathrm{k}]$.

4. A consonant may also precede the templatic vowel, but in this case no consonant may follow. The preceding consonant may be [k] before $[\mathrm{a}]$ and $[\mathrm{o}]$; [ts] before $[\mathrm{i}]$, [a], and $[\mathrm{o}]$; $[\mathrm{t}]$ before [i] and [a]; [S] before [i] and marginally before [a] and [o]; and [s], [3], and [z] only before [i]. That is, most consonants (but not [k]) occur before [i], less before [a], and even less before [o]. A templatic consonant cannot appear before $[\mathrm{u}]$ and $[\varepsilon]$.

5. We may look at the chart in (27) as a markedness hierarchy, where templates on the left and at the top have a larger type frequency than those on the right and at the bottom. It follows that the templates with a single example are all at the marked edges of the hierarchy. Also the templates are in contiguous scales with two exceptions: no [k] before [i] and the $-\mathbf{t}$ fo: template seems to be missing, although there is at least one item in the more marked - $\mathbf{s o :}$ template.

\section{REDUPLICATIVE DIMINUTIVES}

The reduplicative diminutive template is also disyllabic. Typically the first CV of the base is copied, (28a), but there are examples like (28b), where it is not the first part. The reduplicandum is strictly $\mathrm{CV}$, a single consonant and a short vowel, so long vowels are shortened, (28c), and extra consonants are trimmed, (28d). However, word-final [o] must be long due to the 
previously mentioned phonotactic constraint, so while the long [o:] in [mo:nika] is shortened, the final [o:] in [momo:] is still long, ${ }^{39}$ just like in the items in (28e).

Standard descriptions of Hungarian claim that the constraint requiring word-final [o:] to be long extends to another mid vowel, [ø:] (Nádasdy \& Siptár 1994, 63). Indeed, in most words that end in [ø], this vowel is also long. Yet, the constraint does not apply in the reduplicated form in (28f). Since only CV can be reduplicated, the long [ø:] of this base is shortened, and it may remain short in word-final position. ${ }^{40}$

\section{Reduplicative diminutives}
a. [lajof]/[laura] $>$ [lala], [zita] $>$ [zizi], [sabo: $>$ [sasa], [bened $\varepsilon k]>[$ bebe $]$
b. [noe:mi] $>$ [mimi], [3o:fi] $>$ [fifi], [a:gi] $>$ [gigi], [zuza] $>$ [3aza]
c. [mo:nika] $>$ [momo:], [pe:ter] $>$ [pepe]
d. [krifto:f $]>[$ kiki], [silvija] $>[$ sisi $]$
e. [noe:mi] $>$ [nono:], [kova:t] $>$ [koko:], [zolta:n] $>$ [zozo:], [zolt] $>$ [3ozo:]
f. $\quad[$ lø:rints $]>[1 \varnothing l ø] /[1 \varnothing l ø:]$
g. [kokain] $>$ [koko:] 'cocaine', [vivijen] $>$ [vivi], [lilla] $>$ [lili], [zuzanna] $>$ [zuzu]
h. [mama] 'mummy', [papa] 'daddy', [dajka] > [dada] 'nanny', [kaka] 'doo-doo', [pi $\left.\int a\right]>$ [pipi] 'piddle', [ $\left.\int \varepsilon b\right]$ ? > [bibi] 'wound'
i. [tfotfo:] 'table football'

As before, there are some diminutive forms that fit several templates. The items in $(28 \mathrm{~g})$ are both diminutives and examples of the $-\mathbf{o}:, \mathbf{- i}$, and $-\mathbf{u}$ templates. While most of our examples are names, common nouns are also subject to this process. Many of them belong to child language, (28h). This is a rather universal feature of language as some of the English glosses for these words show.

The example in (28i) also seems to belong here, but we could not find out its etymology.

\section{TEMPLATES AND VOWEL HARMONY}

We have already noted that diminutive templates do not contain the front rounded $(\mathrm{F})$ vowels $[ø]$ and $[y]$, only front unrounded, that is, neutral $(\mathrm{N})$, and back (B) vowels. Due to vowel harmony, a disyllabic word (excluding compounds) of Hungarian typically contains one of the vowel pairs in (29a), but not those in (29b).

Common and rare vowel pairs in disyllabic words

a. $\mathrm{BB}, \mathrm{BN}, \mathrm{FF}, \mathrm{FN}, \mathrm{NN}, \mathrm{NB}, \mathrm{NF}$

b. $\mathrm{BF}, \mathrm{FB}$

\footnotetext{
${ }^{39}$ One cannot tell if the first or the second syllable in a reduplicated diminutive is the base. Here we arbitrarily take it to be the first one.

${ }^{40}$ Google has about an equal number of matches for Lölö and Lölö (with the "site:.hu" filter). There are other instances of word-final short [ø]: abbreviations read out as humorous letter names, like $p l$. 'for example', which could be [pe:cl], but

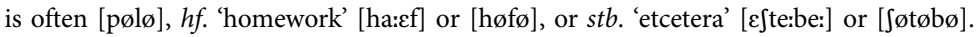


That is, neutral vowels freely combine with both front rounded and back vowels, (29a), but the latter two rarely combine with each other, (29b). ${ }^{41}$ It follows that the templatic vowel in the diminutive of a word containing an F vowel in its truncated stem is not likely to be anything but

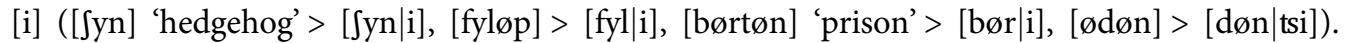
This is indeed the case, diminutive forms like [tynde] $>\%\left[\operatorname{tynd} \mid \mathrm{u} \int\right]$ or [ødøn] $>$ ?[ød|uf] are few and far between, similarly to the rarity of FB stems. ${ }^{42}$ In some diminutive forms we even see an exceptional harmony of the template vowel ([tynde] $>\%\left[\operatorname{tynd} \mid \mathrm{u} \int\right] / \%[\operatorname{tynd} \mid \mathrm{y} f]$ ). This never occurs after a base containing an $\mathrm{N}$ vowel $\left([\mathrm{imr \varepsilon}]>\left[\mathrm{imr} \mid \mathrm{u} \int\right],{ }^{*}\left[\mathrm{imr} \mid \mathrm{y} \int\right]\right.$; [be:la $]>\left[\right.$ be:l $\left.\mid \mathrm{u} \int\right],{ }^{*}\left[\right.$ be:l $\left.\mid \mathrm{y} \int\right]$; [tere:zija] $>$ [ter|uf], *[ter|y $]])$.

No pair of the templates we have identified can be each other's harmonic variants. The templates do not contain an F vowel and apart from word-final [o:], all template vowels are short. This leaves us with only $[\varepsilon]$ and $[a]$ as a possible harmonic alternation in diminutive templates. However, templates with [a] typically do not, while those containing $[\varepsilon]$ must include a consonant after the vowel, so they cannot differ only in their vowel, producing a harmonic pair. Nevertheless, since $\mathrm{F}$ bases are inserted in templates with the $\mathrm{N}$ vowel [i] only ([fyl|i], [døn $\mid$ tsi]), and F vowels do not occur in templates, almost all diminutive forms conform to the common harmony patterns listed in (29a). Except for FF and NF, of course, since there are no templates with $\mathrm{F}$.

As briefly explained at the end of $\$ 3$, polymorphemic words are subject to Harmonic Uniformity. In most cases this requirement applies vacuously. The stems [nul-am] and [nil-am] in (30a) govern back harmony, either because the root vowel is back ([u]) or because it is an antiharmonic neutral vowel ([i]). The stems [fyl-em] and [sil-em] in (30b) govern front harmony, either because the stem vowel is front rounded ([y]) or because it is a harmonic neutral vowel ([i]). In such words any further suffix will simply follow suit.

$$
\begin{aligned}
& \text { Harmony is determined by the root } \\
& \text { a. [nul-am-at] 'rabbit-1SG.POSS-ACC', [nil-am-at] 'arrow-1SG.POSS-ACC' }
\end{aligned}
$$

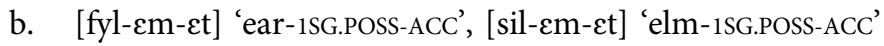

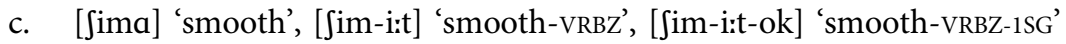

$$
\begin{aligned}
& \text { d. [pisok] 'dirt', [pisk-i:t] 'dirt-VRBZ', [pisk-i:t-ok] 'dirt-VRBZ-1SG' } \\
& \text { e. [ind-i:t] 'start-VRBZ', [ind-i:t-e:k] 'start-VRBZ-NOMZ (=motive)', [indi:te:k-om] } \\
& \text { 'motive-1SG.POSs' }
\end{aligned}
$$

In (30c) the root-final vowel of [ $\mathrm{Sima}$ ] is deleted before the verbalizing suffix. This is important because the deleted vowel is the phonetic carrier of the information that this morpheme governs back harmony. The resulting word [ $\left.\int \mathrm{im}-\mathrm{i}: \mathrm{t}\right]$ contains two neutral vowels, yet it governs back harmony, because the root [jima] also governs back harmony. (30d) shows that the same holds

\footnotetext{
${ }^{41}$ Some recent loanwords provide examples for these patterns: [ 0 ofø:r] 'chauffeur', [kajyt] 'cabin'. There are a few nonalternating back suffixes: [-kor] used in time specifications: [øt-kor] 'at five o'clock' ([øt] 'five', also cf. the free stem [kor] 'age'). In addition there are loan derivative adjectivizer suffixes like [-a:lif]/[-a:rif], [-ikuf], [-ifta], and the verbalizing suffix [-a:l]. The stems these are added to typically do not contain an F vowel.

${ }^{42}$ As we noted on several occasions, in an earlier variety of the language, there were harmonically variable templatic diminutives ([andra: $]$ ] > [ando:], [gergej] > [gerø:] or [gergø:], [domonkof] > [doma], [dømøtør] > [døme]), but such harmonizing templates became inactive.
} 
if the vowel deleted is within the root. This effect is limitless, the root of [ind-i:t-e:k] is [ind-], which is an antiharmonic bound root governing back harmony (cf. [ind-ul] 'start-vRBz'), and, due to Harmonic Uniformity, its derivate [ind-i:t-e:k] also governs back harmony despite containing three neutral vowels.

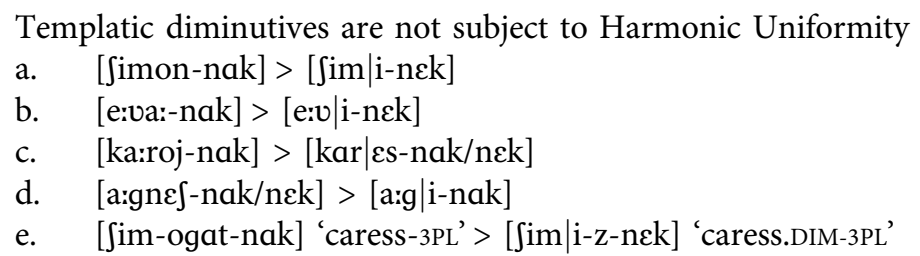

The dative suffix following the nondiminutive and diminutive forms of the names in $(31 \mathrm{a}-\mathrm{d})$ prove that templatic diminutives are not subject to Harmonic Uniformity. In $(31 \mathrm{a}-\mathrm{c})$ the first name contains a back vowel in its last syllable, accordingly the suffix also shows up with its back-vowelled allomorph. In the diminutive forms this back vowel is replaced with a neutral vowel. As a result the names in (31a-b) will govern front harmony, like polysyllabic, monomorphemic words, as we saw in (5f) in $\$ 3$, and unlike the words in (30c-e). In (31c) [kares] vacillates, like [hotel] in (5e) and [a:gnef] in (31d), and unlike its base, [ka:roj]. The diminutive of [a:gnef], [a:gi] does not vacillate like its base, but governs back harmony, like [profil] in (5d). (31e) provides a verbal example: the diminutive verb [Simi-z-] does not inherit the back harmony of its base [Simogat] (itself a derivate of [Sima] 'smooth'), it governs front harmony, like [tsivil] in (5f). That is, templatic diminutive forms do not behave harmonically as a word produced by regular additional morphology behaves.

We conclude a templatic diminutive form is harmonically not related to its base. A templatic diminutive form behaves as a single morpheme for vowel harmony. As such [Simi] and [e:vi] can only govern front harmony, [kares] vacillates, and [a:gi] can only govern back harmony, since they are polysyllabic and, apparently, monomorphemic.

\section{CONCLUSIONS}

In this paper we have discovered several aspects in which additive (agglutinative) morphology $(\mathrm{AM})$, the regular method of inflection and derivation in Hungarian, is different from truncative morphology (TM), applied in the creation of diminutive forms only. One set of differences concern vowel alternations. These are listed in (32).

Vowel alternations

a. vowel shortening: both $\mathrm{AM}$ and $\mathrm{TM},(4 \mathrm{~g}-\mathrm{i}),(12 \mathrm{a})$

b. word-final vowel loss: both AM and TM, (6), (7d)

c. vowel lengthening

- stem-final: only AM, (4f)

- stem-internal: only TM, (12b)

d. word-internal loss of single short vowel: only AM, (4j)

e. proper truncation: only TM, passim 
The shortening of the last vowel and the loss of the final vowel of the stem or base occurs in both additive and truncative processes, $(32 \mathrm{a}-\mathrm{b})$, but this is where the similarities end. Although the stem vowel may lengthen in both types of process, in additive morphology we only find the lengthening of a stem-final low vowel, in truncative morphology it is only a stem-internal vowel that may lengthen, and not only low $[\varepsilon]$ and $[\mathrm{a}]$, but also mid [o]. As for vowel/zero alternations, it is only a single short vowel that may be lost in additive morphology. Truncative morphology, on the other hand, may disappear not only short, but also long vowels, and not only one, but any number of them. (In addition, consonants may also be lost only in this type of process.) Furthermore, while only the last vowel of the stem, potentially followed by a single consonant, may be targeted by additive morphology, truncation can affect any vowel of the base.

It must be pointed out that the output of additive morphology and diminutive truncation may be indistinguishable when the latter targets a single stem-final vowel. The former process cannot target more than one short vowel, as in (33a), but in the diminutive form in (33b) we also see that a single short vowel is lost. However, as we have pointed out above and try to hint at by not using the hyphen as a morpheme boundary symbol, the diminutive form [e:v|i] behaves as a monomorphemic word, which accordingly must govern front harmony (cf. (5f)), and not as a polymorphemic word, like [be:n-i:t], which governs back harmony due to Harmonic Uniformity. In (33) we enclose the target of truncation in angle brackets.

$$
\begin{aligned}
& \text { Word-final vowel loss vs. truncation } \\
& \text { a. [be:n〈a -i:t-ok] 'lame-VRBZ-1SG' (cf. [be:na:-nak] 'lame-DAT') }
\end{aligned}
$$

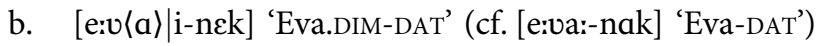

Additive and truncative morphology are also different in the harmonicity of the suffixes (or endings) added to stems/bases. We summarize the possibilities in (34).

$$
\begin{aligned}
& \text { Suffix vowel alternations } \\
& \text { a. harmonizing suffixes: only } \mathrm{AM}^{43} \\
& \text { b. nonharmonizing suffixes } \\
& \text { - back vowel: mostly TM } \\
& \text { - front vowel } \\
& \text { - [i]: both AM and TM } \\
& \text { - [e:]: only AM } \\
& \text { - [ع]: only TM } \\
& -[y(:) ø(:)]: \text { neither }
\end{aligned}
$$

Harmonically alternating suffix allomorphs characterize additive morphology. In truncative diminutives such variants occur only extremely marginally in present-day Hungarian: the templatic $[\mathrm{u}]$ may alternate with $[\mathrm{y}]$, but only marginally and optionally after a front rounded vowel in the base $\left(\left[\right.\right.$ tynd $\left.\mid \mathrm{u} \int\right] \sim[$ tynd $\left.\mid \mathrm{y} f]\right)$. We have seen that the vowels of truncative diminutive templates generally do not alternate harmonically. Nonalternating back suffix vowels do not occur in additive morphology (pace [-kor], some Latinate derivative suffixes, and the verbalizing

\footnotetext{
${ }^{43}$ Pace $\%[$ tynd-y $]$.
} 
[-a:l], see $\$ 8$ ), they are typical of truncative diminutive templates. Nonalternating front rounded vowels do not occur in suffixes at all. It is the front unrounded, that is, neutral vowels that are common in this context. Of these, low $[\varepsilon]$ is limited to truncative morphology, mid [e:] to additive morphology (recall, diminutive template vowels are generally short), and it is the high [i] that may be found in both categories.

So additve morphology and truncative morphology are clearly two subsystems in Hungarian, the properties of which are incompatible to a very large extent.

\section{ACKNOWLEDGEMENTS}

We dedicate this paper to the memory of our teacher, colleague, friend, Ferenc Kiefer (1931-2020).

\section{REFERENCES}

Alber, Birgit. 2010. An exploration of truncation in Italian. Rutgers Working Papers in Linguistics 3. 1-30. Alber, Birgit and Sabine Arndt-Lappe. 2012. Templatic and subtractive truncation. In Jochen Trommer (ed.) The morphology and phonology of exponence. Oxford: Oxford University Press. 289-325. https:// doi.org/10.1093/acprof:oso/9780199573721.003.0009.

Bárczi, Géza. 1931-1932. A „pesti nyelv” [The “language of Pest”]. Magyar Nyelv 27. 228-242, 284-295, 28. 85-96.

Benkő, Loránd, Lajos Kiss and László Papp (eds.). 1967. A magyar nyelv történeti-etimológiai szótára (I-III) [A historical-etymological dictionary of the Hungarian language (I -III)]. Budapest: Akadémiai Kiadó. Halácsy, Péter, András Kornai, László Németh, András Rung, István Szakadát and Viktor Trón. 2004. Creating open language resources for Hungarian. Proceedings of Language Resources and Evaluation Conference (LREC04). 203-210. http://szotar.mokk.bme.hu/szoszablya/searchq.php.

Hayes, Bruce, Péter Siptár, Kye Zuraw and Zsuzsa Londe. 2010. Natural and unnatural constraints in Hungarian vowel harmony. Language 85(5). 822-863. https://doi.org/10.1353/lan.0.0169.

Itô, Junko and Armin Mester. 1997. Sympathy Theory and German truncations. In Viola Miglio and Bruce Morén (eds.) Proceedings of the Hopkins Optimality Workshop/Maryland Mayfest 1997. University of Maryland Working Papers in Linguistics 5. College Park, MD: University of Maryland. 117-139. https://doi.org/doi:10.7282/T32V2D6R.

Janurik, Tamás. 2009. Magyar képzőszótár: A mai magyar köznyelv képzőváltozatai [A dictionary of Hungarian derivational suffixes: The variants of derivational suffixes in present-day colloquial Hungarian]. Budapest: Akadémiai Kiadó.

Kenstowicz, Michael. 2019. The analysis of truncated vocalives in Taviano (Salentino) Italian. Catalan Journal of Linguistics 18. 131-159. https://doi.org/10.5565/rev/catjl.257.

Kiefer, Ferenc (ed.). 2000. Strukturális magyar nyelvtan 3: Morfológia [A structural grammar of Hungarian 3: Morphology]. Budapest: Akadémiai Kiadó.

Kiefer, Ferenc and Mária Ladányi. 2000a. A szóképzés [Word formation]. In Kiefer (2000. 137-164).

Kiefer, Ferenc and Mária Ladányi. 2000b. Morfoszintaktikailag semleges képzések [Morphosyntactically neutral derivations]. In Kiefer (2000. 165-214). 
Ladó, János and Ágnes Bíró. 2005. Magyar utónévkönyv [A book of Hungarian given names]. Budapest: Vince.

Lass, Roger. 1984. Phonology: An introduction to basic concepts. Cambridge: Cambridge University Press.

Nádasdy, Ádám. 1989. Consonant length in recent borrowings into Hungarian. Acta Linguistica Hungarica 39. $195-213$.

Nádasdy, Ádám and Péter Siptár. 1994. A magánhangzók [Vowels]. In Ferenc Kiefer (ed.) Strukturális magyar nyelvtan 2: Fonológia [A structural grammar of Hungarian 2: Phonology]. Budapest: Akadémiai Kiadó. 42-182.

Papp, Brigitta. 2018. Pipicici, szemcsi, burgi és társai - te melyik szó becézésétől mászol falra? [Pipicici, szemcsi, burgi and so on - which pet term makes you hit the roof?] https://fmc.hu/2018/05/23/pipiciciszemcsi-burgi-es-tarsai-te-melyik-szo-becezesetol-maszol-falra. (Retrieved 2020-12-20).

Patay, Fanni. 2019. Similarity effects in vowel harmony. MA dissertation. Eötvös Loránd University, Budapest.

Prieto, Pilar. 1992. Truncation processes in Spanish. Studies in the Linguistic Sciences 22(1). 143-158.

Rebrus, Péter and Péter Szigetvári. 2016. Diminutives: Exceptions to Harmonic Uniformity. Catalan Journal of Linguistics 15. 101-119. https://doi.org/10.5565/rev/catjl.186.

Rebrus, Péter and Péter Szigetvári. 2020. Depixelating phonotactics: A complexity-based typology of consonant clusters. Ms. Eötvös Loránd University, Budapest.

Rebrus, Péter and Miklós Törkenczy. 2019. Magyar harmónia: a dolgok állása [Hungarian vowel harmony: The way things are]. Általános Nyelvészeti Tanulmányok XXXI. 233-333.

Schneider, Klaus P. 2003. Diminutives in English. Tübingen: Max Niemeyer Verlag.

Siptár, Péter and Miklós Törkenczy. 2000. The phonology of Hungarian. Oxford: Oxford University Press. Sóskuthy, Márton and Péter Rácz. 2020. Beyond plain and extra-grammatical morphology: Echo-pairs in Hungarian. Language and Speech. https://doi.org/10.1177/0023830920932955.

Thornton, Anna M. 1996. On some phenomena of prosodic morphology in Italian: Accorciamenti, hypocoristics and prosodic delimitation. Probus 8. 81-112. https://doi.org/10.1515/prbs.1996.8.1.81.

Tompa, József. 1964. A becéző szó eleji névrövidítés a mai szóalkotásmódok rendszerében [Word-initial diminutive truncation in the current system of word formation]. Magyar Nyelv 60. 89-92.

Törkenczy, Miklós. 2011. Hungarian vowel harmony. In Marc van Oostendorp, Colin J. Ewen, Elizabeth Hume and Keren Rice (eds.) The Blackwell companion to phonology. Malden, MA \& Oxford: WileyBlackwell. 2963-2990. https://doi.org/10.1002/9781444335262.wbctp0123.

Törkenczy, Miklós. 2016. Hungarian vowel harmony. In Mark Aronoff (ed.) Oxford bibliographies in linguistics. New York, NY: Oxford University Press. https://doi.org/10.1093/obo/9780199772810-0134.

T. Somogyi, Magda. 2017. Kicsinyítő-becéző képzőink történetéről [On the history of Hungarian diminutive-hypocoristic suffixes]. A nyelvtörténeti kutatások újabb eredményei 9. 287-302.

Vago, Robert. 1980. The sound pattern of Hungarian. Washington, D.C.: Georgetown University Press. van de Weijer, Jeroen. 1989. The formation of diminutive names in Hungarian. Acta Linguistica Hungarica 39. 353-371.

Open Access. This is an open-access article distributed under the terms of the Creative Commons Attribution 4.0 International License (https://creativecommons.org/licenses/by/4.0/), which permits unrestricted use, distribution, and reproduction in any medium, provided the original author and source are credited, a link to the CC License is provided, and changes - if any - are indicated. (SID_1) 